\title{
Hypoxia increases chemoresistance in human medulloblastoma DAOY cells via hypoxia-inducible factor $1 \alpha$-mediated downregulation of the CYP2B6, CYP3A4 and CYP3A5 enzymes and inhibition of cell proliferation
}

\author{
JESÚS VALENCIA-CERVANTES ${ }^{1,5}$, SARA HUERTA-YEPEZ ${ }^{2}$, GUILLERMO AQUINO-JARQUÍN ${ }^{3}$, \\ SARA RODRÍGUEZ-ENRÍQUEZ ${ }^{4}$, DANIEL MARTÍNEZ-FONG ${ }^{1}$, \\ JOSÉ-ANTONIO ARIAS-MONTAÑO ${ }^{1}$ and VÍCTOR MANUEL DÁVILA-BORJA ${ }^{5}$ \\ ${ }^{1}$ Department of Physiology, Biophysics and Neurosciences, Center for Research and Advanced Studies (Cinvestav), \\ Mexico City 07360; ${ }^{2}$ Oncology Disease Research Unit, Children's Hospital of Mexico 'Federico Gomez'; \\ ${ }^{3}$ Laboratory of Research on Genomics, Genetics and Bioinformatics, Haemato-Oncology Building, \\ Children's Hospital of Mexico 'Federico Gomez', Mexico City 06720; \\ ${ }^{4}$ Department of Biochemistry,National Institute of Cardiology 'Ignacio Chavez', Mexico City 14080; \\ ${ }^{5}$ Laboratory of Experimental Oncology, National Institute of Pediatrics, \\ Mexico City 04530, Mexico
}

Received February 1, 2018; Accepted September 17, 2018

DOI: $10.3892 /$ or.2018.6790

\begin{abstract}
Medulloblastomas are among the most frequently diagnosed pediatric solid tumors, and drug resistance remains as the principal cause of treatment failure. Hypoxia and the subsequent activation of hypoxia-inducible factor $1 \alpha(\mathrm{HIF}-1 \alpha)$ are considered key factors in modulating drug antitumor effectiveness, but the underlying mechanisms in medulloblastomas have not yet been clearly understood. The aim of the present study was to determine whether hypoxia induces resistance to cyclophosphamide (CPA) and ifosfamide (IFA) in DAOY medulloblastoma cells, whether the mechanism is dependent on HIF-1 $\alpha$, and whether involves the modulation of the expression of cytochromes P450 (CYP)2B6, 3A4 and 3A5 and the control of cell proliferation. Monolayer cultures of DAOY medulloblastoma cells were exposed for $24 \mathrm{~h}$ to moderate $\left(1 \% \mathrm{O}_{2}\right)$ or severe $\left(0.1 \% \mathrm{O}_{2}\right)$ hypoxia, and protein
\end{abstract}

Correspondence to: Dr Víctor Manuel Dávila-Borja, Laboratory of Experimental Oncology, National Institute of Pediatrics, Research Tower, 3700-C Insurgentes Sur Avenue, Insurgentes Cuicuilco, Mexico City 04530, Mexico

E-mail: latrans86@hotmail.com

Dr José-Antonio Arias-Montaño, Department of Physiology, Biophysics and Neurosciences, Center for Research and Advanced Studies (Cinvestav), Mexico City 07360, Mexico

E-mail: jaarias@fisio.cinvestav.mx

Key words: tumor hypoxia, hypoxia-inducible factor $1 \alpha$, cy tochrome P-450 enzyme system, drug resistance, medulloblastoma expression was evaluated by immunoblotting. Cytotoxicity was studied with the MTT assay and by Annexin V/PI staining and flow cytometry. Cell proliferation was determined by the trypan-blue exclusion assay and cell cycle by propidium iodide staining and flow cytometry. Hypoxia decreased CPA and IFA cytotoxicity in medulloblastoma cells, which correlated with a reduction in the protein levels of CYP2B6, CYP3A4 and CYP3A5 and inhibition of cell proliferation. These responses were dependent on hypoxia-induced HIF-1 $\alpha$ activation, as evidenced by chemical inhibition of its transcriptional activity with 2-methoxyestradiol (2-ME), which enhanced the cytotoxic activity of CPA and IFA and increased apoptosis. Our results indicate that by stimulating $\mathrm{HIF}-1 \alpha$ activity, hypoxia downregulates the expression of CYP2B6, CYP3A4 and CYP3A5, that in turn leads to decreased conversion of CPA and IFA into their active forms and thus to diminished cytotoxicity. These results support that the combination of HIF-1 $\alpha$ inhibitors and canonical antineoplastic agents provides a potential therapeutic alternative against medulloblastoma.

\section{Introduction}

Medulloblastomas comprise 15 to $20 \%$ of all the central nervous system (CNS) primary pediatric malignant tumors, and have recently been classified into four molecular subgroups: Wingless (WNT), Sonic hedgehog (SHH) and the numerical groups 3 and 4, which display differences in disease course and clinical outcome $(1,2)$. Current advances in medulloblastoma diagnosis, in combination with therapeutic regimens with surgery, craniospinal radiotherapy or chemotherapy, have contributed to an increase in the 5-year survival rate of up to $80 \%$ (2). However, drug resistance remains as one of the most 
difficult barriers to overcome, and is frequently associated with therapeutic failure, elevated morbidity rates, relapses and long-term sequelae in neurocognitive development $(3,4)$.

Most solid tumors exhibit zones characterized by gradients of low oxygen tension, termed hypoxia, a condition considered to be a key factor in the promotion of resistance to diverse chemotherapeutic agents in CNS tumors, including medulloblastoma (3,5). Moderate to severe hypoxia (2.5-0.1\% $\mathrm{O}_{2}$, respectively), has for example been documented in astrocytomas, oligodendrogliomas and glioblastoma multiforme (6). Cellular responses to oxygen variations are regulated by HIF-1 (hypoxia-inducible factor 1), a heterodimeric transcription factor constituted by the HIF-1 $\alpha$ subunit, whose expression, protein stability and sub-cellular localization depend on $\mathrm{O}_{2}$ levels, and HIF-1 $\beta$, a nuclear subunit constitutively expressed (7). HIF-1 $\alpha$ overexpression has been associated with the resistance of several types of tumors to a variety of drugs (8-12), supporting the hypothesis that hypoxia and the HIF-1 pathway contribute to modulate the effectiveness and toxicity of anticancer chemotherapeutic drugs (13).

The standard treatment of medulloblastoma includes antineoplastic pro-drugs such as cyclophosphamide (CPA) and ifosfamide (IFA), whose antitumoral activity requires chemical transformation to produce alkylating cytotoxic intermediary metabolites, a mechanism that depends on redox reactions catalyzed predominantly by the cytochrome $\mathrm{P} 450$ (CYP) isoforms 2B6, 3A4 and 3A5 (14). These heme-thiolated enzymes display differential expression in several solid tumors, including osteosarcoma, breast, prostate and lung cancers (15-18), and is widely accepted that alterations in the tumor expression of CYP enzymes contribute to changes in the metabolic deactivation of anticancer agents or the activation of pro-drugs $(19,20)$. However, to date, little is known concerning CYP expression in medulloblastomas.

Recent studies demonstrated that moderate hypoxia $\left(1 \% \mathrm{O}_{2}\right)$ downregulates CYP3A4 expression in the human hepatocarcinoma HepG2 cell line, resulting in decreased metabolic activation of antineoplastic acridine compounds $(21,22)$. Furthermore, CYP2B6 selectively mediates the activation of the pro-drug AQN4 to the cytotoxin AQ4 in hypoxic cells (23), evidencing that limited oxygen availability in tumors may alter drug metabolism and therapeutic effectiveness, mainly by interfering with the regulation of CYP expression, with consequences for chemoresistance (21,24-26).

Despite intense research focusing on elucidating the relationship between hypoxia and tumor drug resistance, the underlying mechanisms in medulloblastomas have not been clearly delineated. In this study, we showed that the in vitro exposure of DAOY medulloblastoma cells to moderate $\left(1 \% \mathrm{O}_{2}\right)$ or severe $\left(0.1 \% \mathrm{O}_{2}\right)$ hypoxia, produced resistance to CPA or IFA, characterized by increased half-maximal inhibitory concentration values $\left(\mathrm{IC}_{50}\right)$, alongside decreased protein levels of CYP2B6, CYP3A4 and CYP3A5, inhibition of cell proliferation and arrest in the G1 phase of the cell cycle. These responses depended on the activation of the HIF-1 pathway, as evidenced by the fact that the chemical inhibition of its transcriptional activity with 2-methoxyestradiol (2-ME) acted in an additive manner with CPA or IFA to exert cytotoxic activity and increase apoptosis.

\section{Materials and methods}

Reagents. Cyclophosphamide monohydrate, ifosfamide, MTT [3-(4, 5-dimethylthiazol-2-yl)-2, 5-diphenyltetrazolium bromide], propidium iodide (PI) and RNase A were purchased from Sigma-Aldrich; Merck KGaA (Darmstadt, Germany). 2-Methoxyestradiol (2-ME) was obtained from Tocris Bioscience (Bristol, UK). The antibodies used and their sources were: Rabbit polyclonal anti-HIF-1 $\alpha$ (cat. no. NB100-449), from Novus Biologicals (Littleton, CO, USA); mouse monoclonal anti-CA-IX (cat. no. sc365900), mouse monoclonal anti-PCNA (proliferating cell nuclear antigen) (cat. no. sc-25280), goat anti-rabbit IgG (cat. no. sc-2004) and rabbit anti-goat IgG (cat. no. sc-2768), from Santa Cruz Biotechnology (Santa Cruz, CA,USA); rabbit monoclonal anti-CYP2B6 (cat. no. ab140609), rabbit polyclonal anti-CYP3A4 (cat. no. ab135813), rabbit polyclonal anti-CYP3A5 (cat. no. ab89811) and mouse monoclonal anti-CDKN1B (cyclin-dependent kinase inhibitor 1B) (cat. no. ab54563) from Abcam (Cambridge, MA, USA); mouse monoclonal anti- $\alpha$-actin (cat. no. GTX80809) and goat anti-mouse IgG (cat. no. GTX213111-01), were purchased from GeneTex (Irvine, CA, USA).

Cell culture and hypoxic conditions. Monolayer cultures of DAOY cells (human desmoplastic cerebellar medulloblastoma cell line; HTB-186; ATCC, Manassas, VA, USA) were routinely maintained in Eagle's minimal essential medium (EMEM) supplemented with $10 \%$ fetal bovine serum (FBS; Biowest, Riverside, CA, USA), $100 \mathrm{U} / \mathrm{ml}$ penicillin and $100 \mu \mathrm{g} / \mathrm{ml}$ streptomycin (Gibco; Thermo Fisher Scientific, Inc., Waltham, MA, USA), at $37^{\circ} \mathrm{C}$ in a humidified atmosphere of $95 \%$ air and $5 \% \mathrm{CO}_{2}$. Normoxia was considered as $16.2 \% \mathrm{O}_{2}\left(\mathrm{ppO}_{2}\right.$ $588 \mathrm{~mm} \mathrm{Hg}$ ) as México City is located 2,240 m above sea level. Hypoxia was generated by a pre-equilibrated Bactrox hypoxic chamber (Shel Lab; Sheldon Manufacturing, Inc., Cornelius, OR, USA) and oxygen was balanced with $\mathrm{N}_{2}$ and $\mathrm{CO}_{2}$. Once $90 \%$ confluence was reached, medulloblastoma cells were incubated for $24 \mathrm{~h}$ under moderate $\left(1 \% \mathrm{O}_{2}\right)$ or severe $\left(0.1 \% \mathrm{O}_{2}\right)$ hypoxia.

Immunoblot analysis/western blotting. Total, cytosolic and nuclear protein extracts were processed according to Jewell et al (27). Briefly, cells were grown in EMEM supplemented with $10 \%$ FBS and antibiotics in T-75 culture flasks $\left(10^{6}\right.$ cells) until $90 \%$ confluence was reached. The medium was replaced by fresh medium and cells were then incubated in normoxia or hypoxia for $24 \mathrm{~h}$. Adherent cells were scraped in $200 \mu \mathrm{l}$ cell lysis buffer $(10 \mathrm{mM}$ Tris- $\mathrm{HCl} \mathrm{pH}$ 8.0, $1 \mathrm{mM}$ EDTA and $150 \mathrm{mM} \mathrm{NaCl}$ ), containing 0.5\% IGEPAL (Sigma-Aldrich; Merck KGaA), $1 \mathrm{mM}$ Mini-Complete protease inhibitor cocktail (Roche; Mannheim, Germany) and $1 \mathrm{mM}$ PMSF (Sigma-Aldrich; Merck KGaA). Samples were incubated for $10 \mathrm{~min}$ on ice before centrifugation at 20,000 x g for $5 \mathrm{~min}$ at $4^{\circ} \mathrm{C}$. Cytosolic proteins were removed and pellets were re-suspended in nuclear extraction buffer (20 mM HEPES, $\mathrm{pH}$ 7.9, $400 \mathrm{mM} \mathrm{NaCl}, 1 \mathrm{mM}$ EDTA and $1 \mathrm{mM}$ DTT), incubated on ice for $15 \mathrm{~min}$, and then vortexed and centrifuged at $20,000 \times \mathrm{g}$ for $5 \mathrm{~min}$ at $4^{\circ} \mathrm{C}$. Total cell lysates were prepared using $100 \mu \mathrm{l}$ RIPA buffer (Sigma-Aldrich; Merck KGaA). After centrifugation $\left(4,000 \times \mathrm{g}, 20 \mathrm{~min}, 4^{\circ} \mathrm{C}\right)$, protein levels 
were determined by the Bradford colorimetric assay, using bovine serum albumin (BSA) as standard reference.

Nuclear (30 $\mu \mathrm{g}$ protein), cytosolic $(30 \mu \mathrm{g})$ and total (30-50 $\mu \mathrm{g}$ ) lysates were electrophoretically separated using $8-12 \%$ SDS-PAGE and proteins were then transferred to polyvinylidene difluoride membranes (Immobilon-P; Millipore, Temecula, CA, USA). Membranes were blocked with 5\% non-fat dry milk in Tris-buffered saline solution (TBS; $50 \mathrm{mM}$ Tris- $\mathrm{HCl}, \mathrm{pH} 7.5,150 \mathrm{mM} \mathrm{NaCl}$ ) containing $0.1 \%$ Tween-20 (Sigma-Aldrich; Merck KGaA) at room temperature for $1 \mathrm{~h}$, followed by overnight incubation with primary antibodies: HIF-1 $\alpha$ (1:2,000 dilution); CA-IX, (1:200); PCNA $(1: 1,000)$; CYP2B6 (1:2,000); CYP3A4 (1:3,000); CYP3A5 (1:2,000); CDKN1B (1:200) and $\alpha$-actin $(1: 10,000)$. After extensive washing with TBS, membranes were incubated for $1 \mathrm{~h}$ with horseradish peroxidase-conjugated secondary antibodies: goat anti-mouse $\operatorname{IgG}(1: 3,000)$, goat anti-rabbit $\operatorname{IgG}(1: 3,000)$ or rabbit anti-goat IgG (1:5,000). Protein signals were detected by chemiluminescence using the Immobilon ${ }^{\mathrm{TM}}$ Western HRP substrate (Millipore; Merck KGaA), and images were captured with Bio-Rad Fluor S Max MultiImager and analyzed with Quantity One 1-D Analysis Software version 4.4.1 (Bio-Rad Laboratories, Inc., Hercules, CA, USA). Protein levels were expressed as relative optical density, normalized with respect to the levels of an internal control ( $\alpha$-actin), with the exception of nuclear HIF-1 $\alpha$, normalized to PCNA levels.

Immunocytochemistry. DAOY cells $\left(10^{4}\right.$ cells/well) were grown in EMEM supplemented with $10 \%$ FBS and antibiotics in Lab-Tek-8 well chambers. After $24 \mathrm{~h}$, the medium was replaced by fresh medium, and cells were incubated in normoxic or hypoxic conditions for $24 \mathrm{~h}$. Cells were then fixed for $20 \mathrm{~min}$ in $4 \%$ formalin in water (w/v), and rinsed twice with ice-cold phosphate-buffered saline solution (PBS; $137 \mathrm{mM} \mathrm{NaCl}, 2.7 \mathrm{mM} \mathrm{KCl}, 10 \mathrm{mM} \mathrm{NaHPO}_{4}, 2 \mathrm{mM} \mathrm{KH}_{2} \mathrm{PO}_{4}$, $\mathrm{pH}$ 7.4). Samples were incubated in antigen retrieval buffer (10 mM sodium citrate, $\mathrm{pH} \mathrm{6.0)} \mathrm{for} 15 \mathrm{~min}$ at $95^{\circ} \mathrm{C}$ and then rinsed three times with ice-cold PBS. Endogenous peroxidases were blocked with $\mathrm{H}_{2} \mathrm{O}_{2}(3 \%$, v/v, in methanol) for $15 \mathrm{~min}$ and cells were then rinsed with distilled $\mathrm{H}_{2} \mathrm{O}$ and PBS for $5 \mathrm{~min}$. Non-specific binding was blocked with normal swine serum $(2 \%, \mathrm{v} / \mathrm{v}$, in PBS) at room temperature for $1 \mathrm{~h}$. Cells were then incubated overnight at room temperature in blocking solution containing an anti-HIF- $1 \alpha$ antibody (1:1,000 dilution) in a humidified chamber. The Biotinylated Link Universal Secondary Antibody (Dako; Agilent Technologies, Inc., Santa Clara, CA, USA) and streptavidin conjugated with horseradish peroxidase (cat. no. K069011) were used as secondary antibodies. Color was generated by adding the substrate 3'3-diaminobenzidine (1:1,000 dilution) for $1 \mathrm{~min}$, and counterstaining was performed with hematoxylin. Finally, the cells were subsequently dehydrated in 70, 90 and $100 \%$ ethanol, ethanol-xylene (1:1) and xylene (100\%), and then covered with resin. Images were obtained with Image-Pro Plus (Aperio; Leica Biosystems, Inc., Buffalo Grove, IL, USA) with an Olympus BX-40 Microscope (Olympus Corp., Center Valley, PA, USA).

Determination of cellular density and viability by the trypan-blue exclusion assay. DAOY cells were grown in
EMEM supplemented with 10\% FBS and antibiotics in 6-well plates $\left(2 \times 10^{5}\right.$ cells/well) and cultured for $24 \mathrm{~h}$. The medium was replaced by fresh medium before incubation under normoxic and hypoxic conditions for $24 \mathrm{~h}$. The medium was then removed, cells were rinsed twice with $5 \mathrm{ml}$ ice-cold PBS and then incubated with $400 \mu 10.25 \%$ trypsin-EDTA for $5 \mathrm{~min}$. The trypsin action was terminated with $2 \mathrm{ml}$ supplemented EMEM medium. Cells (1:5 dilution) were exposed to $0.4 \%$ trypan-blue solution in $300 \mu \mathrm{l}$ PBS for $10 \mathrm{~min}$ and the number of cells was determined by using a Neubauer chamber. CPA and IFA were dissolved in EMEM at a final concentration of $100 \mathrm{mM}$. 2-ME was dissolved in DMSO (5 mM stock), and stored at $-20^{\circ} \mathrm{C}$ until required. All dilutions were freshly prepared before addition to the cells. The DMSO final concentration was $0.1 \%$ to avoid cellular damage.

MMT assay. DAOY cells were grown in EMEM supplemented with $10 \%$ FBS and antibiotics in 96-well plates $\left(5 \times 10^{3}\right.$ cells/well) and incubated for $24 \mathrm{~h}$ at $37^{\circ} \mathrm{C}$ and $5 \%$ $\mathrm{CO}_{2}$. Thereafter, the cells were exposed to CPA or IFA (0.1-100 $\mathrm{mM}$ ) under normoxic or hypoxic conditions for $24 \mathrm{~h}$. In parallel determinations, cells were incubated under the described conditions in the presence of 2-ME $(5-40 \mu \mathrm{M})$. Control experimentation was performed in cells treated with the corresponding vehicles. After $48 \mathrm{~h}$ of total incubation, cells were analyzed with the MTT assay. Briefly, $10 \mu \mathrm{l}$ of an MTT solution $(5 \mathrm{mg} / \mathrm{ml}$ sterile water) was added to the cells for $3 \mathrm{~h}$. The medium was removed and $100 \mu \mathrm{l}$ MTT solvent $(4 \mathrm{mM}$ $\mathrm{HCl}$ and $0.1 \%$ IGEPAL in isopropyl alcohol) was added and the plate was placed on an orbital shaker for $15 \mathrm{~min}$ at $25^{\circ} \mathrm{C}$. Spectrophotometrically determinations at $560 \mathrm{~nm}$ were then performed (Modulus $^{\mathrm{TM}}$ II Microplate; Turner BioSystems, Inc.; Thermo Fisher Scientific, Inc.).

Cell cycle distribution. Cell cycle distribution was analyzed using the modified assay described by Box and Demetrick (28). Cells $\left(2 \times 10^{5}\right.$ cells/well) were grown in EMEM supplemented with $10 \%$ FBS and antibiotics in 6-well plates. After $24 \mathrm{~h}$ the medium was replaced by fresh medium and cells were incubated under normoxia or hypoxia for $24 \mathrm{~h}$. The cells were then washed and trypsinized with $400 \mu 10.25 \%$ trypsin-EDTA for $5 \mathrm{~min}$. The trypsin action was terminated with $2 \mathrm{ml}$ supplemented EMEM medium, the cell suspension was centrifuged $\left(200 \times \mathrm{g}, 5 \mathrm{~min}, 4^{\circ} \mathrm{C}\right)$ and the pellet was re-suspended in $1 \mathrm{ml}$ PBS containing $1 \mathrm{mM}$ EDTA. Absolute ethanol $(2.3 \mathrm{ml}$, $-20^{\circ} \mathrm{C}$ ) was added and the suspension was stored overnight at $-20^{\circ} \mathrm{C}$. The cell suspension was centrifuged at $200 \mathrm{x} \mathrm{g}$ for $5 \mathrm{~min}$, re-suspended in $500 \mu \mathrm{l}$ DNA extraction buffer $(0.2 \%$ Triton X-100 in PBS) and kept for $10 \mathrm{~min}$ at room temperature. Cells were centrifuged again at $200 \mathrm{x} \mathrm{g}$ for $5 \mathrm{~min}$ at $4^{\circ} \mathrm{C}$ and the pellet was re-suspended in $200 \mu 1$ RNAase A solution $(1 \mathrm{mg} / \mathrm{ml})$ and kept for $10 \mathrm{~min}$ at room temperature, centrifuged at $200 \mathrm{x}$ g for $5 \mathrm{~min}$, re-suspended in $500 \mu \mathrm{l} \mathrm{PBS}$; $15 \mu \mathrm{l}$ propidium iodide solution $(1 \mathrm{mg} / \mathrm{ml})$ were added and the mixture was incubated for $50 \mathrm{~min}$ at room temperature in the dark. After centrifugation at $200 \mathrm{x} \mathrm{g}\left(5 \mathrm{~min}, 4^{\circ} \mathrm{C}\right)$, cells were re-suspended in $400 \mu \mathrm{l}$ PBS. Flow cytometry was performed with BD LSRFortessa ${ }^{\mathrm{TM}}$ equipment (BD Biosciences, San Jose, CA, USA) and the cell cycle was analyzed using ModFit LT software (Verity Software House, Topsham, ME, USA). 
Apoptosis assay. DAOY cells $\left(2 \times 10^{5}\right.$ cells/well) were grown in EMEM supplemented with $10 \%$ FBS and antibiotics in 6-well plates for $24 \mathrm{~h}$ and then exposed to CPA and IFA ( $\mathrm{IC}_{50}$ values determined previously, see Results) in the absence or presence of $2-\mathrm{ME}(5 \mu \mathrm{M})$. The medium was then removed and the cells were rinsed twice with $5 \mathrm{ml}$ ice-cold PBS and trypsinized with $400 \mu 10.25 \%$ trypsin-EDTA for $5 \mathrm{~min}$. The trypsin action was terminated with $2 \mathrm{ml}$ supplemented EMEM medium. After centrifugation at $200 \times \mathrm{g}\left(5 \mathrm{~min}, 4^{\circ} \mathrm{C}\right)$, cells were re-suspended in $1 \mathrm{ml}$ PBS ( $1 \mathrm{mM}$ EDTA). The apoptotic cell fraction was revealed with Annexin V/PI according to the protocol of the Annexin V Apoptosis Detection Kit FITC (eBiosciences; Thermo Fisher Scientific, Inc.). Flow cytometry was performed with BD LSRFortessa ${ }^{\mathrm{TM}}$ and apoptosis was analyzed with Cyflogic software (CyFlo Ltd., Turku, Finland).

Effect of drug combinations. The cytotoxic effects of CPA or IFA plus 2-ME were analyzed by determining the resistance index (RI), with the following equation: $\mathrm{RI}=\mathrm{Se}(1 \mathrm{x} 2) /$ So $(1+2)$, where experimental survival (Se) is the product of the survival observed with drug 1 and the survival observed with drug 2 , and survival observed (So) is the survival observed with the drug combination of 1 and 2 . RI values $>1$ indicate additive effects, whereas RI $>2$ indicates synergistic effects (29).

Statistical analysis. Data are expressed as means \pm standard error (SEM). The statistical analysis was performed with Prism 5.0 (GraphPad Software, La Jolla, CA, USA). Data were compared with one-way ANOVA followed by post hoc Tukey's or Dunnett's tests, or with two-way ANOVA followed by Bonferroni's test. Probability values $(\mathrm{P})<0.05$ were considered statistically significant.

\section{Results}

Hypoxia activates the HIF-1 $\alpha$ pathway and upregulates CA-IX expression in medulloblastoma cells. Cell hypoxia limits the post-translational chemical modifications of HIF-1 $\alpha$, leading to increased protein stabilization and subsequent translocation to the nucleus, triggering thus the transcriptional regulation of diverse genes (7). Considering that in solid tumors gradients of low oxygen levels coexist, and in order to examine the possible differences in protein stabilization of HIF- $1 \alpha$ in response to oxygen variations, in a first approach DAOY medulloblastoma cells were exposed to 1 or $0.1 \% \mathrm{O}_{2}$ for $24 \mathrm{~h}$, and the expression levels of HIF-1 $\alpha$ were analyzed by western blot analysis and immunocytochemistry.

As expected, hypoxia increased the nuclear and cytosolic protein levels of HIF-1 $\alpha$ in medulloblastoma cells, by 3- to 5-fold in $1 \% \mathrm{O}_{2}$, and by 3 - to 6 -fold in $0.1 \% \mathrm{O}_{2}$ (Fig. $1 \mathrm{~A}$ and $\mathrm{B}$ ). Of note, there was no significant difference in the magnitude of the HIF-1 $\alpha$ induction between both hypoxic conditions. Activation of the HIF-1 $\alpha$ pathway by hypoxia leads to the transcriptional regulation of numerous target genes, including the gene codifying for CA-IX, which plays a significant role in the modulation of the extracellular $\mathrm{pH}$, is therefore considered as a biomarker of hypoxia, and is clinically associated to poor survival outcome in CNS tumors (30). In the present study, optical density analysis of the immunoblots for CA-IX was performed on the bands corresponding to the transmembrane protein (Fig. 1C), and showed increased expression in cells incubated in either $1 \% \mathrm{O}_{2}$ (19-fold) or $0.1 \% \mathrm{O}_{2}$ (22-fold). Likewise for HIF-1 $\alpha$ levels, changes in CA-IX protein levels in response to hypoxia did not depend on the hypoxia levels, 1 or $0.1 \% \mathrm{O}_{2}$ (Fig. 1A-C). These results indicate that in DAOY cells moderate or severe hypoxia activates the HIF-1 $\alpha$ signaling pathway to a similar extent.

HIF-1 $\alpha$ nuclear and cytosolic distribution was corroborated by immunocytochemical analysis. Under $1 \% \mathrm{O}_{2}$, the fraction of cells positive to cytosolic HIF- $1 \alpha$ increased from $7.5 \%$ (normoxia) to $84 \%$, whereas the fraction positive for nuclear expression increased from $2.0 \%$ (normoxia) to $62 \%$. Under $0.1 \% \mathrm{O}_{2}$, the fraction of cells with cytosolic HIF-1 $\alpha$ immunoreactivity increased from 7.5 to $78 \%$ and the fraction with nuclear immunoreactivity increased from 2.0 to $67 \%$ (Figs. 2A and B, and 3). There was no statistical difference between cells incubated in 1 or $0.1 \% \mathrm{O}_{2}$.

Hypoxia increases the resistance to the cytotoxic effect of the pro-drugs CPA and IFA. HIF-1 $\alpha$ overexpression has been associated with the resistance of diverse solid tumors to a variety of drugs (8-12). Current chemotherapeutic regimens for medulloblastoma include the use of the pro-drugs CPA and IFA that undergo complex metabolic activation to produce intermediary metabolites and finally the phosphoramide mustard compounds that act as DNA alkylating agents (31). Resistance to the CPA or IFA cytotoxic effect promoted by hypoxia was analyzed on the basis of changes in the concentrations required to halve the viability of medulloblastoma cells $\left(\mathrm{IC}_{50}\right) \cdot \mathrm{IC}_{50}$ values calculated for CPA and IFA under normoxia were 19 and $15 \mathrm{mM}$, respectively (Table I). Under $1 \% \mathrm{O}_{2}$ the $\mathrm{IC}_{50}$ values for CPA and IFA increased by 2- and 1.5-fold, respectively, whereas under $0.1 \% \mathrm{O}_{2}$ the $\mathrm{IC}_{50}$ values increased by 2 - and 3 -fold, respectively, indicating a reduction in the cytotoxic activity for both hypoxic conditions (Table I). Although these chemotherapeutic agents share metabolic activation pathways and antineoplastic mechanisms, slight differences were observed in the effect of hypoxia; for example, for CPA there was no statistical difference in the $\mathrm{IC}_{50}$ values between 1 and $0.1 \% \mathrm{O}_{2}$, but for IFA the $\mathrm{IC}_{50}$ value obtained under $0.1 \% \mathrm{O}_{2}$ was significantly different from the value obtained under $1 \% \mathrm{O}_{2}$ (Table I).

Hypoxia inhibits the expression of the CYP2B6, CYP3A4 and CYP3A5 enzymes. The expression of various functionally active CYP enzymes has been documented in diverse tumors, supporting a role in the oxidative metabolism of a range of anticancer drugs (19). Specifically, the CYP2B6, CYP3A4 and CYP3A5 isoforms are important for the biotransformation of CPA and IFA to produce intermediary hydroxylated metabolites and exert their antitumor activity $(14,32)$. However, to the best of our knowledge there is no information on CYP2B6, CYP3A4 and CYP3A5 expression in regards to medulloblastomas. For this reason, we initially evaluated the protein expression of CYP2B6, CYP3A4 and CYP3A5 by DAOY cells. Detectable protein levels of these CYP enzymes were visualized by western blotting, and were compared with positive controls of expression (HepG2 cell line), to corroborate the similar electrophoretic mobility in SDS-PAGE (data not shown). When the hypoxia effect on CYP isoform expression 

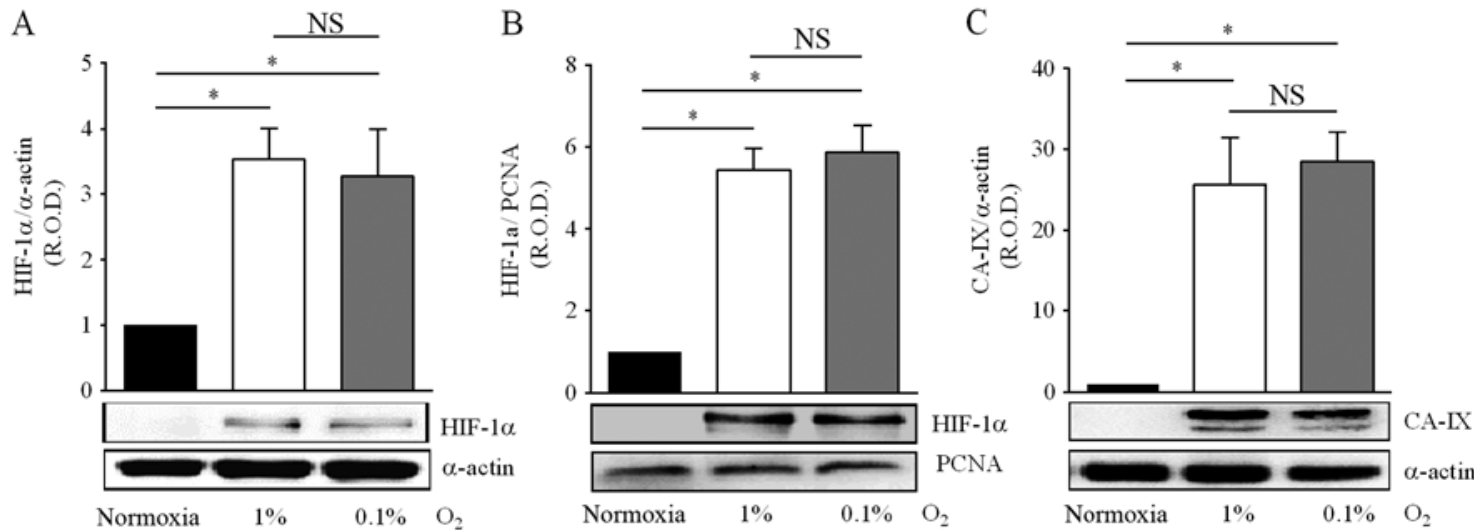

Figure 1. Effect of hypoxia on HIF-1 $\alpha$ and CA-IX expression in DAOY cells. Cells were incubated under normoxia $\left(16.2 \% \mathrm{O}_{2}\right)$ or hypoxia $\left(1\right.$ or $\left.0.1 \% \mathrm{O}_{2}\right)$ for $24 \mathrm{~h}$. Representative immunoblots of HIF-1 $\alpha$ in cytosolic (A) and nuclear (B) extracts are shown. (C) Hypoxia ( 1 or $\left.0.1 \% \mathrm{O}_{2}\right)$ increased the protein levels of transmembrane CA-IX, a hypoxia biomarker. The companion graphs correspond to the analysis of the relative optical density (R.O.D.) from four independent experiments (means $\pm \mathrm{SEM}$ ). ${ }^{*} \mathrm{P}<0.05$; NS, no significant difference; the statistical analysis was performed with one-way ANOVA and Tukey's test.
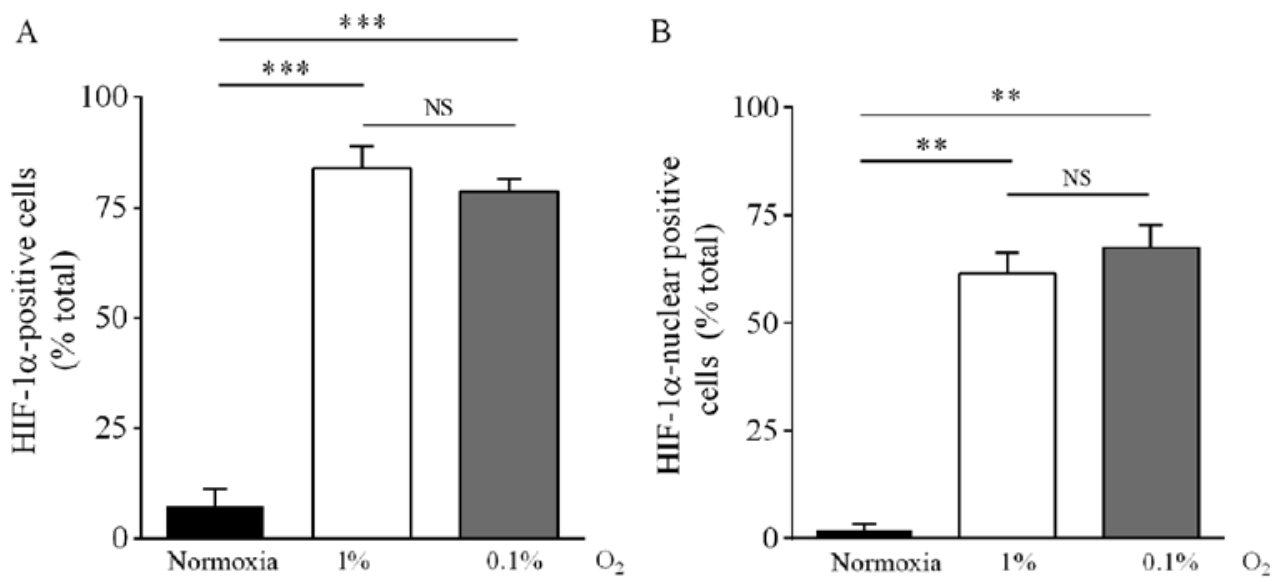

Figure 2. Effect of hypoxia on HIF-1 $\alpha$ immunoreactivity in DAOY cells. Cells were incubated under normoxia $\left(16.2 \% \mathrm{O}_{2}\right)$ or hypoxia $\left(1\right.$ or $\left.0.1 \% \mathrm{O}_{2}\right)$ for $24 \mathrm{~h}$, and then stained with an antibody against HIF-1 $\alpha$. Positive cells (A) and cells with nuclear immunoreactivity (B) were quantified in three independent experiments. ${ }^{* *} \mathrm{P}<0.01,{ }^{* * *} \mathrm{P}<0.001 ; \mathrm{NS}$, no significant difference; one-way ANOVA and Tukey's test.

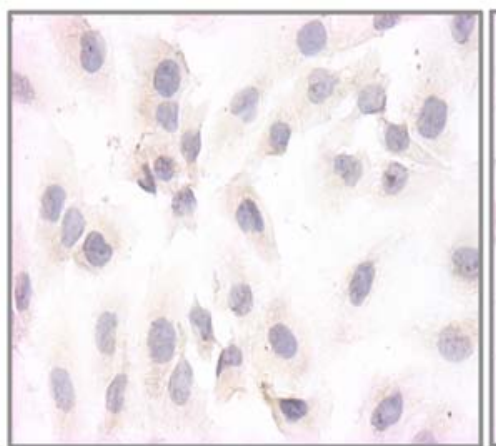

Normoxia

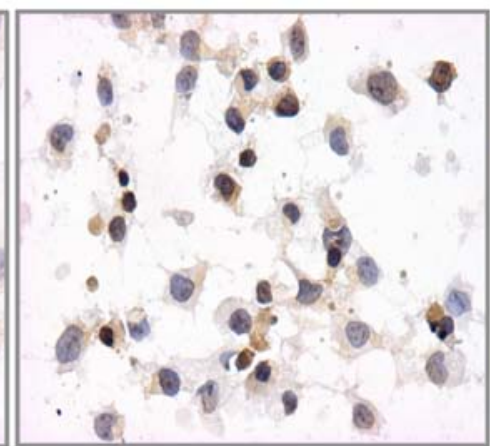

$1 \% \mathrm{O}_{2}$

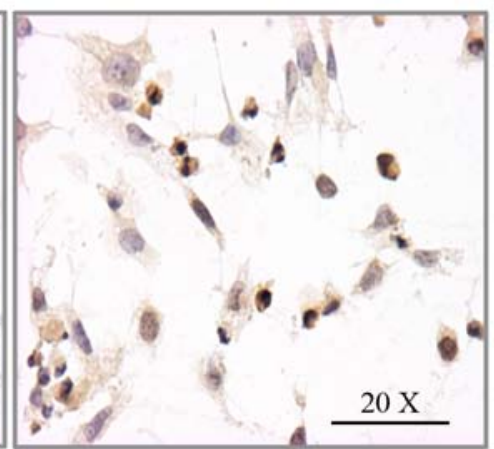

$0.1 \% \mathrm{O}_{2}$

Figure 3. Cellular and nuclear HIF-1 $\alpha$ immunoreactivity in response to hypoxia in DAOY cells. After incubation for $24 \mathrm{~h}$ in normoxia $\left(16.2 \% \mathrm{O}_{2}\right)$ or hypoxia $\left(1\right.$ or $0.1 \% \mathrm{O}_{2}$ ) DAOY cells were stained with an antibody against HIF-1 $\alpha$. Images are representative of three independent experiments. The quantitative analysis is shown in Fig. 2.

was analyzed, incubation in 1 and $0.1 \% \mathrm{O}_{2}$ produced a significant decrease in CYP2B6 protein levels (-50 and $-70 \%$, respectively), in comparison with DAOY cells maintened under normoxic conditions (Fig. 4A).
Similar results were obtained for the CYP3A4 and CYP3A5 enzymes, with incubation in 1 or $0.1 \% \mathrm{O}_{2}$ reducing by $30 \%$ the protein levels of both proteins (Fig. 4B and C). For all three CYP isoforms, the decrease in protein levels was not significantly 
Table I. Effect of hypoxia on the cytotoxic action of CPA or IFA in DAOY cells.

\begin{tabular}{cccccccr}
\hline & \multicolumn{3}{c}{$\mathrm{CPA}$} & \multicolumn{3}{c}{$\mathrm{IFA}$} \\
\cline { 2 - 3 } $\mathrm{O}_{2}(\%)$ & $\mathrm{pIC}_{50}$ & $\mathrm{IC}_{50}(\mathrm{mM})$ & $\mathrm{n}$ & & $\mathrm{pIC}_{50}$ & $\mathrm{IC}_{50}(\mathrm{mM})$ & $\mathrm{n}$ \\
\hline 16.2 & $1.73 \pm 0.05$ & 18.6 & 7 & & $1.83 \pm 0.06$ & 14.75 & 5 \\
1 & $1.44 \pm 0.06^{\mathrm{a}}$ & 36.1 & 7 & & $1.65 \pm 0.04^{\mathrm{a}}$ & 22.4 & 5 \\
0.1 & $1.43 \pm 0.05^{\mathrm{a}}$ & 36.8 & 5 & & $1.32 \pm 0.08^{\mathrm{a}, \mathrm{b}}$ & 47.5 & 5 \\
\hline
\end{tabular}

Cells were incubated for $24 \mathrm{~h}$ in normoxia $\left(16.2 \% \mathrm{O}_{2}\right)$ or hypoxia $\left(1\right.$ or $\left.0.1 \% \mathrm{O}_{2}\right)$ in the absence and the presence of CPA or IFA, and cell viability was determined with the MTT assay. Values for the $\log _{10}$ of the $\mathrm{IC}_{50}$ estimates $\left(\mathrm{pIC}_{50}\right)$ are the means \pm SEM from the indicated number of experiments. ${ }^{a} \mathrm{P}<0.05$ when compared with normoxia; ${ }^{\mathrm{b}} \mathrm{P}<0.05$ when compared with $1 \% \mathrm{O}_{2}$; one-way ANOVA and Tukey's test. CPA, cyclophosphamide; IFA, ifosfamide.
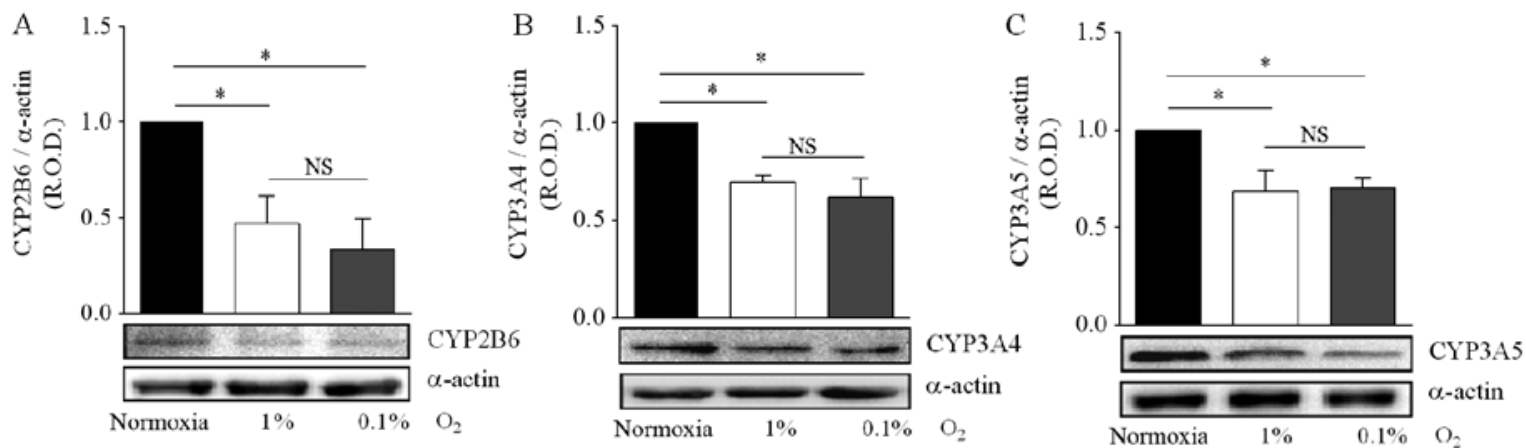

Figure 4. Effect of hypoxia on CYP isoform expression. DAOY cells were incubated for $24 \mathrm{~h}$ under normoxia $\left(16.2 \% \mathrm{O}_{2}\right)$ or hypoxia $\left(1 \mathrm{or} 0.1 \% \mathrm{O}_{2}\right)$. The expression of CYP2B6 (A), CYP3A4 (B) and CYP3A5 (C) was determined by immunoblotting. Representative blots are shown. For graphs, values are means \pm SEM of the relative optical density (R.O.D.) from four independent experiments. " $\mathrm{P}<0.05$; NS, no significant difference; one-way ANOVA and Tukey's test.

Table II. Effect of hypoxia on the cell cycle distribution of DAOY cells.

\begin{tabular}{cccc}
\hline & \multicolumn{3}{c}{ Cell cycle phase $(\%)$} \\
\cline { 2 - 4 } $\mathrm{O}_{2}(\%)$ & $\mathrm{G} 1$ & $\mathrm{~S}$ & $\mathrm{G} 2-\mathrm{M}$ \\
\hline 16.2 & $56.9 \pm 0.4$ & $33.5 \pm 0.4$ & $9.7 \pm 0.1$ \\
1 & $77.0 \pm 0.3^{\mathrm{a}}$ & $15.6 \pm 1.0^{\mathrm{a}}$ & $7.4 \pm 1.1^{\mathrm{NS}}$ \\
0.1 & $73.1 \pm 0.5^{\mathrm{a}}$ & $19.2 \pm 0.4^{\mathrm{a}}$ & $7.7 \pm 0.1^{\mathrm{NS}}$ \\
\hline
\end{tabular}

Cells were incubated for $24 \mathrm{~h}$ in normoxia $\left(16.2 \% \mathrm{O}_{2}\right)$ or hypoxia $\left(1\right.$ or $0.1 \% \mathrm{O}_{2}$ ) and the phases of the cell cycle were evaluated by flow cytometry after staining with iodide propidium. Values are means \pm SEM from three independent experiments. ${ }^{a} \mathrm{P}<0.05$, NS, no significant difference, when compared with normoxia values; one-way ANOVA and Tukey's test.

different between the two hypoxic conditions (Fig. 4A-C). Together, these results indicate that hypoxia reduces the expression of CYP isoforms, leading to a possible reduction in the metabolism of CPA and IFA, and thus to drug resistance.

Hypoxia arrests medulloblastoma cells in the G1 phase, increases the expression of CDKNIB and inhibits cell proliferation. The alkylating intermediary metabolites derived from CPA and IFA by the action of CYP enzymes, react to form chemical cross-links within DNA strands, leading to cell apoptosis, an action affected by the distribution of the cell cycle $(33,34)$. Incubation in 1 or $0.1 \% \mathrm{O}_{2}$ increased the fraction of DAOY cells in the G1 phase and decreased the cell population in the $\mathrm{S}$ phase (Table II). Fig. 5A shows that hypoxia also decreased the number of cells to $70.4 \pm 8.7$ and $68.6 \pm 4.7 \%$ of the values for normoxia in 1 or $0.1 \% \mathrm{O}_{2}$, respectively. The arrest of the cell cycle is controlled by several cyclins, and an increase in CDKN1B is important for arrest in the G1 phase (35). Fig. 5B and $\mathrm{C}$ show that incubation of DAOY cells under hypoxic conditions increased CDKN1B levels to $216 \pm 36$ and $223 \pm 26 \%$ of normoxia values for 1 and $0.1 \% \mathrm{O}_{2}$, respectively. These results suggest that hypoxia induces cell arrest, which in turn may reduce the alkylating effect of CPA and IFA.

Effect of the chemical inhibition of HIF-1 $\alpha$ on hypoxia-induced changes in cell viability and in the expression of CYP2B6, CYP3A4, CYP3A5 and CDKN1B. Our results suggested that in DAOY medulloblastoma cells hypoxia induced resistance to CPA or IFA via activation of the HIF-1 $\alpha$ signaling pathway, which was correlated with decreased expression of the CYP2B6, CYP3A4 and CYP3A5 enzymes, inhibition of cell proliferation and arrest of the cell cycle in the G1 phase. In order to evaluate whether these mechanisms are dependent on HIF-1 $\alpha$, we next investigated the effects of the inhibition 
A

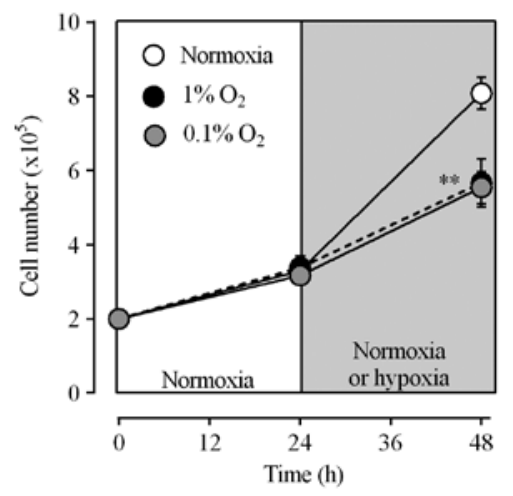

B

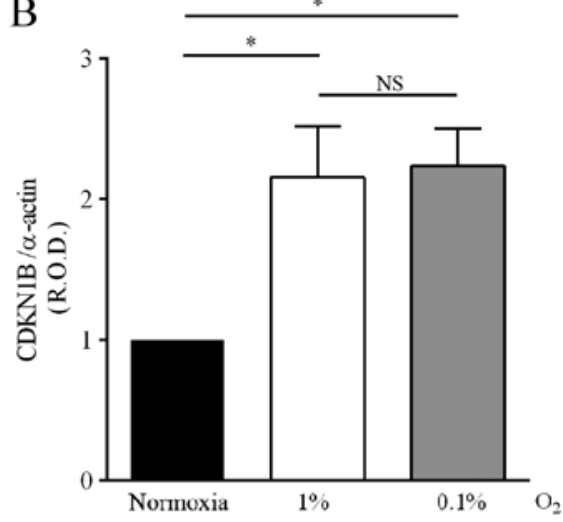

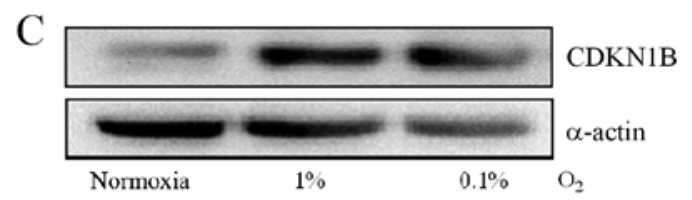

Figure 5. Effect of hypoxia on cell number and CDKN1B expression. Cells were incubated for $24 \mathrm{~h}$ under normoxia $\left(16.2 \% \mathrm{O}_{2}\right)$ and then for a further $24 \mathrm{~h}$ under normoxia or hypoxia $\left(1\right.$ or $\left.0.1 \% \mathrm{O}_{2}\right)$. (A) Cell number was determined with the trypan blue exclusion assay. Values are means \pm SEM from three independent experiments with triplicate determinations. ${ }^{* *} \mathrm{P}<0.01$ vs. normoxia; one-way ANOVA and Dunnett's test. (B) Expression of CDKN1B protein. (C) Representative blots. For panel B, values are means \pm SEM of the relative optical density (R.O.D.) from four independent experiments. "P<0.05; NS, no significant difference; one-way ANOVA and Tukey's test.
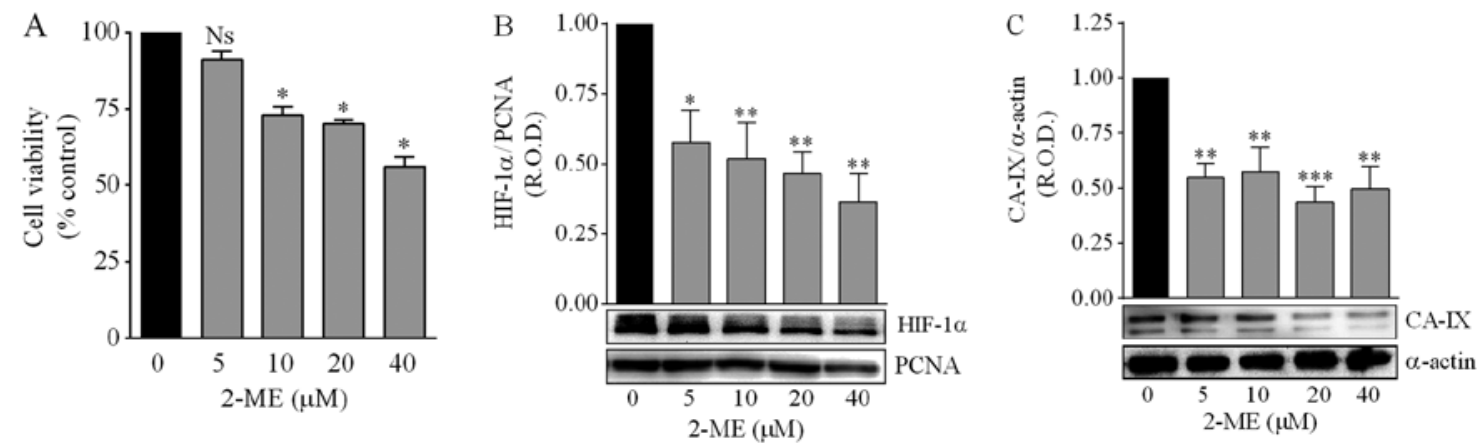

Figure 6. Effect of 2-methoxyestradiol (2-ME) on cell viability, HIF-1 $\alpha$ and CA-IX expression. (A) Cell viability was determined by the MTT assay. Cells were incubated for $24 \mathrm{~h}$ under normoxia $\left(16.2 \% \mathrm{O}_{2}\right)$ in the absence and the presence of the indicated concentrations of 2-ME. Values are means \pm SEM from four independent experiments. " $\mathrm{P}<0.001$, NS, no significant difference vs. control values (without 2-ME); one-way ANOVA and Dunnett's test. (B) Effect of 2-ME and hypoxia on HIF-1 $\alpha$ nuclear levels. DAOY cells were incubated for $24 \mathrm{~h} \mathrm{in} 1 \% \mathrm{O}_{2}$ in the absence and the presence of the indicated concentrations of 2-ME. Representative blots are shown. For the graph, values are means \pm SEM of the relative optical density (R.O.D.) from four independent experiments. ${ }^{*} \mathrm{P}<0.05,{ }^{* *} \mathrm{P}<0.01$ vs. control values (without 2-ME); one-way ANOVA and Dunnett's test. (C) Effect of 2-ME and hypoxia on CA-IX levels. DAOY cells were incubated for $24 \mathrm{~h}$ in $1 \% \mathrm{O}_{2}$ in the absence and the presence of the indicated concentrations of 2-ME. Representative blots are shown. For the graph, values are means \pm SEM of the relative optical density (R.O.D.) from four independent experiments. ${ }^{* *} \mathrm{P}<0.01,{ }^{* * * *} \mathrm{P}<0.001$ vs. control values (without 2 -ME); one-way ANOVA and Dunnett's test.

pharmacologically, with 2-methoxyestradiol (2-ME) of the transcriptional activity of HIF-1 $\alpha$ (36).

Concentrations of 2-ME $>5 \mu \mathrm{M}$ significantly decreased the viability of DAOY cells (Fig. 6A). Treatment with 2-ME $(5-40 \mu \mathrm{M})$ significantly reduced the nuclear expression of HIF- $1 \alpha$ in a concentration-dependent manner (Fig. 6B), as well as the protein levels of the hypoxia biomarker CA-IX, although in this case the effect did not depend on the 2-ME concentration (Fig. 6C). Considering these results, and in order to analyze the consequences of inhibiting the HIF-1 $\alpha$ pathway on the mechanisms associated with drug resistance described in the present study, $5 \mu \mathrm{M}$ was chosen as the 2-ME optimal concentration. This concentration prevented the reduction in cell number provoked by either 1 or $0.1 \% \mathrm{O}_{2}$ (Fig. 7A). Furthermore, both 0.1 and $1 \% \mathrm{O}_{2}$ increased the expression of CDKN1B by medulloblastoma cells, although treatment with 2-ME prevented this effect only in cells incubated in $1 \% \mathrm{O}_{2}$ (Fig. 7B and C).

Hypoxia inhibited CYP2B6 expression, and incubation of medulloblastoma cells with $5 \mu \mathrm{M} 2$-ME prevented the effect of $1 \% \mathrm{O}_{2}$ but not that of $0.1 \% \mathrm{O}_{2}$ (Fig. 8A). CYP3A4 expression was also reduced by incubation in either 1 or $0.1 \% \mathrm{O}_{2}$, and 2-ME prevented the effect of both hypoxic conditions (Fig. 8B). CYP3A5 expression was reduced by incubation 

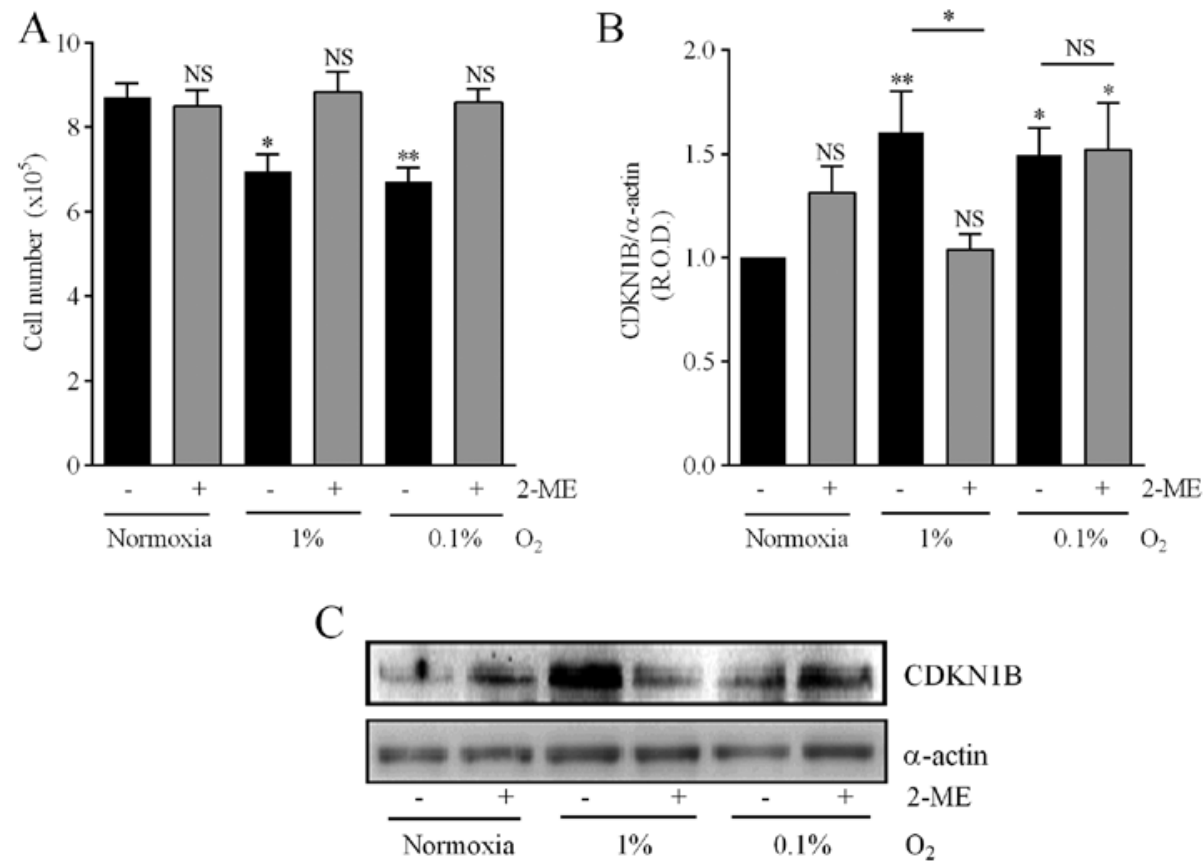

Figure 7. Effect of 2-methoxyestradiol (2-ME) on hypoxia-induced reduction in cell number and CDKN1B expression. (A) Effect of 2-ME on hypoxia-induced reduction in cell number. Cells were incubated for $24 \mathrm{~h}$ under normoxia $\left(16.2 \% \mathrm{O}_{2}\right)$ or hypoxia $\left(1 \mathrm{or} 0.1 \% \mathrm{O}_{2}\right)$ in the absence and the presence of 2 -ME $(5 \mu \mathrm{M})$ and cell number was evaluated with the trypan blue exclusion assay. Values are means \pm SEM from three independent experiments. ${ }^{*} \mathrm{P}<0.05,{ }^{* *} \mathrm{P}<0.01$ vs. control values in normoxia and in the absence of 2-ME; NS, no significant difference; two-way ANOVA and Bonferroni's test. (B) Effect of 2-ME on hypoxia-induced CDKN1B expression. Cells were incubated under normoxia $\left(16.2 \% \mathrm{O}_{2}\right)$ or hypoxia $\left(1 \mathrm{or} 0.1 \% \mathrm{O}_{2}\right)$ for $24 \mathrm{~h}$. (C) Representative immunoblots are depicted. The companion graphs represent the means \pm SEM of the relative optical density (R.O.D.) from four independent experiments. ${ }^{*} \mathrm{P}<0.05$, ${ }^{* *} \mathrm{P}<0.01$ vs. values in normoxia and without 2-ME; NS, no significant difference; two-way ANOVA and Bonferroni's test.
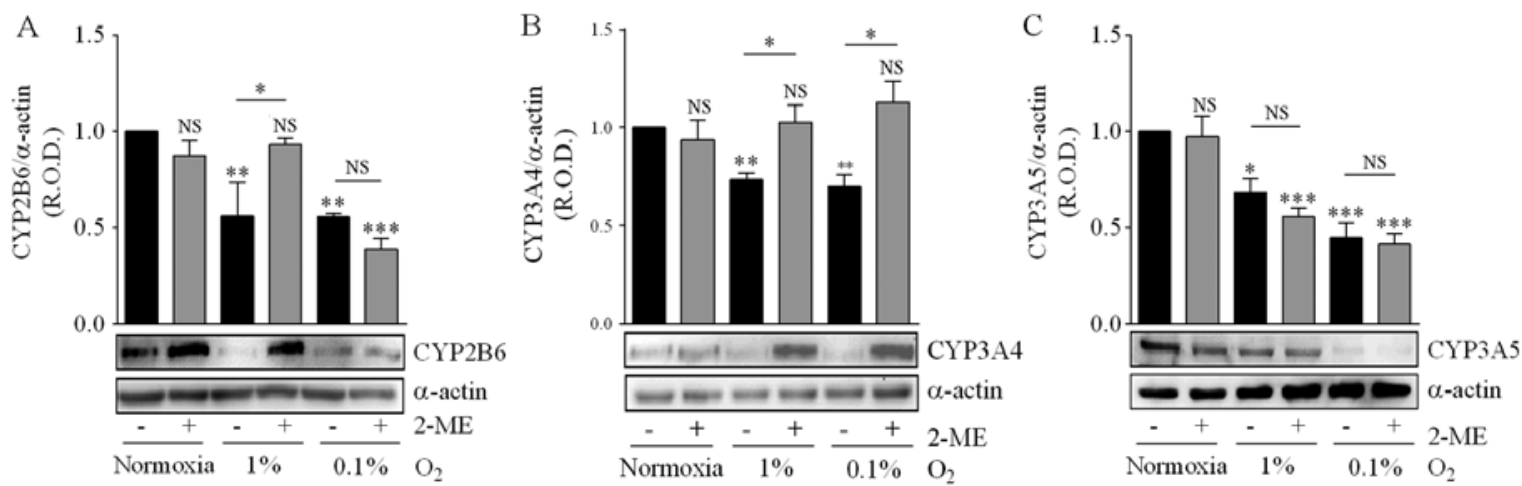

Figure 8. Effect of 2-methoxyestradiol (2-ME) on hypoxia-induced downregulation of the expression of CYP isoforms. Cells were incubated under normoxia $\left(16.2 \% \mathrm{O}_{2}\right)$ or hypoxia $\left(1\right.$ or $\left.0.1 \% \mathrm{O}_{2}\right)$ for $24 \mathrm{~h}$ and the expression of CYP2B6 (A), CPY3A4 (B) and CPY3A5 (C) was determined by immunoblotting. Representative immunoblots are depicted. The companion graphs represent the means \pm SEM of the relative optical density (R.O.D.) from three independent experiments. ${ }^{*} \mathrm{P}<0.05,{ }^{* *} \mathrm{P}<0.01,{ }^{* * *} \mathrm{P}<0.001$ vs. values in normoxia and without 2-ME; NS, no significant difference; two-way ANOVA and Bonferroni's test.

in 1 and $0.1 \% \mathrm{O}_{2}$, but in this case 2-ME did not prevent this effect (Fig. 8C). These results indicate that HIF-1 $\alpha$ inhibition differentially affects the action of hypoxia on the expression of these CYP isoforms.

2-ME sensitizes medulloblastoma cells to CPA and IFA cytotoxicity. Treatment with CPA or IFA alone or in combination with 2-ME $(5 \mu \mathrm{M})$ was tested under normoxic and hypoxic conditions, using the $\mathrm{IC}_{50}$ values for CPA or IFA as previously determined (Table I). Table III shows that under normoxia the reduction in cell viability induced by CPA $(-43.2 \pm 1.7 \%)$ or IFA $(-46.3 \pm 2.2 \%)$ was not significantly modified by 2 -ME $(-45.8 \pm 3.3$ and $-51.4 \pm 2.0 \%$ for CPA and
IFA, respectively). In contrast, in cells incubated under $1 \% \mathrm{O}_{2}$, the reduction in cell viability induced by CPA $(-45.7 \pm 1.9 \%)$ or IFA $(-50.3 \pm 2.5 \%)$ was significantly enhanced by the presence of 2-ME, to $-72.7 \pm 2.1$ and $-76.4 \pm 2.3 \%$, respectively. Likewise, under $0.1 \% \mathrm{O}_{2}, 2-\mathrm{ME}$ increased the cytotoxic effect of both CPA and IFA from $-44.5 \pm 1.5$ and $-51.2 \pm 2.9 \%$ to $-69.8 \pm 2.1$ and $-73.5 \pm 1.9 \%$, respectively.

The resistance index (RI) for cells incubated in normoxia was not significantly greater than that observed for CPA or IFA in combination with 2-ME. In contrast, the analysis showed that CPA and 2-ME additively decreased cell viability in $1 \% \mathrm{O}_{2}$ (RI $1.9 \pm 0.1$ ) and $0.1 \% \mathrm{O}_{2}$ (RI 1.7 \pm 0.1$)$. IFA and 2-ME synergistically decreased cell viability in $1 \% \mathrm{O}_{2}$ (RI 2.0 \pm 0.1 ) 
Table III. Cytotoxicity induced by CPA or IFA alone or in combination with 2-ME.

\begin{tabular}{|c|c|c|c|c|c|}
\hline $\mathrm{O}_{2}(\%)$ & 2-ME & $\mathrm{CPA}$ & $\mathrm{CPA}+2-\mathrm{ME}$ & $\mathrm{R}$ index & Effect \\
\hline 16.2 & $94.35 \pm 7.3$ & $56.8 \pm 1.7^{\mathrm{a}}$ & $54.2 \pm 3.3$ & $0.99 \pm 0.06$ & No effect \\
\hline 1 & $95.6 \pm 7.0$ & $54.3 \pm 1.9^{\mathrm{a}}$ & $27.3 \pm 2.1^{\mathrm{b}}$ & $1.92 \pm 0.13^{\mathrm{c}}$ & Additivity \\
\hline \multirow[t]{2}{*}{0.1} & $93.2 \pm 3.0$ & $55.5 \pm 1.5^{\mathrm{a}}$ & $30.2 \pm 2.1^{\mathrm{b}}$ & $1.74 \pm 0.11^{\mathrm{c}}$ & Additivity \\
\hline & 2-ME & IFA & $\mathrm{IFA}+2-\mathrm{ME}$ & $\mathrm{R}$ index & Effect \\
\hline 16.2 & $93.9 \pm 1.0$ & $53.7 \pm 2.2^{\mathrm{a}}$ & $48.6 \pm 2.0$ & $1.04 \pm 0.02$ & No effect \\
\hline 1 & $94.4 \pm 1.2$ & $49.7 \pm 2.5^{\mathrm{a}}$ & $23.6 \pm 2.3^{b}$ & $2.03 \pm 0.12^{\mathrm{c}}$ & Synergy \\
\hline 0.1 & $95.4 \pm 1.6$ & $48.8 \pm 2.9^{\mathrm{a}}$ & $26.5 \pm 1.9^{b}$ & $1.77 \pm 0.10^{\mathrm{c}}$ & Additivity \\
\hline
\end{tabular}

Cells were incubated for $24 \mathrm{~h}$ under normoxia $\left(16.2 \% \mathrm{O}_{2}\right)$ or hypoxia $\left(1\right.$ or $\left.0.1 \% \mathrm{O}_{2}\right)$ with CPA or IFA in the absence and the presence of 2-ME $(5 \mu \mathrm{M})$ and cell viability was determined with the MTT assay. Values are expressed as the percentage of the control cell viability (no drugs added) and are means \pm SEM from five independent experiments. ${ }^{\mathrm{a}} \mathrm{P}<0.001 \mathrm{vs.} 2 \mathrm{ME}$; ${ }^{\mathrm{b}} \mathrm{P}<0.01 \mathrm{vs}$. CPA or IFA alone; ${ }^{\mathrm{P}} \mathrm{P}<0.01 \mathrm{vs}$. the R index of cells incubated under normoxia; one-way ANOVA and Tukey's test. The R index was calculated as described in Materials and methods. 2-ME, 2-methoxyestradiol; CPA, cyclophosphamide; IFA, ifosfamide.

Table IV. Apoptosis induced by CPA or IFA alone or in combination with 2-ME.

\begin{tabular}{lccc}
\hline & \multicolumn{3}{c}{ Annexin $\mathrm{V}^{+} / \mathrm{IP}^{+}$cells $(\%)$} \\
\cline { 2 - 4 } & $16.2 \% \mathrm{O}_{2}$ & $1 \% \mathrm{O}_{2}$ & $0.1 \% \mathrm{O}_{2}$ \\
\hline Control & $5.5 \pm 1.1$ & $11.0 \pm 2.1$ & $6.1 \pm 2.5$ \\
2-ME & $9.7 \pm 3.8^{\mathrm{a}}$ & $19.4 \pm 5.7^{\mathrm{a}}$ & $13.9 \pm 2.1^{\mathrm{a}}$ \\
$\mathrm{CPA}$ & $22.5 \pm 2.8$ & $62.9 \pm 1.4$ & $38.2 \pm 4.7$ \\
$\mathrm{CPA}+2-\mathrm{ME}$ & $27.6 \pm 4.7^{\mathrm{b}}$ & $78.8 \pm 2.4^{\mathrm{b}}$ & $68.9 \pm 6.6^{\mathrm{d}}$ \\
IFA & $24.0 \pm 4.4$ & $67.8 \pm 1.1$ & $42.0 \pm 1.7$ \\
IFA+2-ME & $22.9 \pm 4.5$ & $86.6 \pm 2.7^{\mathrm{c}}$ & $75.9 \pm 2.6^{\mathrm{e}}$ \\
\hline
\end{tabular}

Cells were incubated for $24 \mathrm{~h}$ in normoxia $\left(16.2 \% \mathrm{O}_{2}\right)$ or hypoxia $\left(1\right.$ or $\left.0.1 \% \mathrm{O}_{2}\right)$ with CPA $(18.6 \mathrm{mM})$ or IFA $(14.7 \mathrm{mM})$ in the absence or the presence of 2-ME $(5 \mu \mathrm{M})$, and apoptosis was evaluated with Annexin V-FITC/PI staining and flow cytometry. Values are means \pm SEM from three independent experiments. ${ }^{a} \mathrm{P}<0.05$ vs. control values; ${ }^{\mathrm{b}} \mathrm{P}<0.05$ vs. CPAalone; ${ }^{\mathrm{P}} \mathrm{P}<0.01$ vs. IFA alone; ${ }^{\mathrm{d}} \mathrm{P}<0.001$ vs. CPA alone; ${ }^{\mathrm{e}}<0.001$ vs. IFA alone. The statistical analysis was performed with one-way ANOVA and Tukey's test. PI, propidium iodide; 2-ME, 2-methoxyestradiol; CPA, cyclophosphamide; IFA, ifosfamide.

and additively in $0.1 \% \mathrm{O}_{2}$ (RI $\left.1.8 \pm 0.1\right)$. These results suggest that the combination of CPA or IFA with 2-ME enhances the effectiveness of the treatment in cells exposed to hypoxic conditions.

Inhibition of HIF-1 $\alpha$ by 2-ME increases the apoptotic effect of CPA and IFA. Table IV shows that the fraction of apoptotic cells (Annexin $\mathrm{V}^{+} / \mathrm{PI}^{+}$) significantly increased in DAOY cells incubated in $1 \% \mathrm{O}_{2}$ and treated with CPA in combination with $2-\mathrm{ME}(78.8 \pm 2.4 \%)$ as compared with cells treated with CPA alone $(62.9 \pm 1.4 \%)$. Likewise, treatment with IFA in combination with 2-ME significantly increased the fraction of apoptotic cells $(86.6 \pm 2.7$ vs. $67.8 \pm 1.1 \%$ for IFA alone). Similar results were obtained for DAOY cells incubated in $0.1 \% \mathrm{O}_{2}$, for which the fraction of apoptotic cells increased significantly in cells treated with CPA and 2-ME $(68.9 \pm 6.6 \%)$ compared with CPA alone $(38.2 \pm 4.7 \%)$, and in cells treated with IFA plus 2-ME $(75.9 \pm 2.6 \%)$ compared with IFA alone $(42.0 \pm 1.7 \%)$. These results indicate that HIF-1 $\alpha$ inhibition enhances the apoptotic effect of CPA and IFA under hypoxic conditions.

\section{Discussion}

In CNS tumors the presence of hypoxia has been correlated with a more aggressive behavior (6), and in several other cancer types the activation of the HIF-1 $\alpha$ pathway in response to variations in oxygen concentration was found to increase tumor resistance to diverse chemotherapeutic agents (7-11). Oxygen deprivation leads to the immediate cytosolic stabilization of HIF-1 $\alpha$ and its subsequent nuclear translocation to dimerize with HIF-1 $\beta$ and modulate transcriptionally the expression of diverse genes (7).

Herein we showed that in human medulloblastoma DAOY cells, hypoxia increased the cytosolic and nuclear protein levels of HIF-1 $\alpha$, and that this effect was correlated with a high expression of CA-IX, a transmembrane protein with an extracellular domain that catalyzes the reversible conversion of $\mathrm{CO}_{2}$ to bicarbonate and is involved in the regulation of the extracellular $\mathrm{pH}$ (37). CA-IX overexpression is consistently associated with poor survival in diverse malignancies, including medulloblastoma (38), and in this neoplasia it modulates E-cadherin-mediated cell adhesion via its interaction with $\beta$-catenin, leading to increased tumor progression (39). Furthermore, CA-IX has been reported to be an endogenous sensor of HIF-1 activity due to the presence of a hypoxia response element (HRE) sequence located immediately upstream of the transcription start (40), and the concomitant high expression of HIF-1 $\alpha$ and CA-IX was found to be correlated with chemoresistance in lung cancer (41), similar to that observed in the present study for CPA and IFA in medulloblastoma cells. 
Chemical transformation of CPA and IFA is performed by diverse hepatic CYP enzymes, including CYP2B6, CYP3A4 and CYP3A5 (14), and it is widely recognized that the expression of these enzymes in tumor cells may contribute in situ to changes in the metabolic activation of these pro-drugs (19). In relation to medulloblastoma, Liu et al documented a link between the expression of CYP1A1 and CYP1B1 and its enzymatic functionality in the metabolic activation of resveratrol in the medulloblastoma UW228-3 cell line (42). In the present study, the CYP2B6, CYP3A4 and CYP3A5 isoforms were detectable at the protein level in DAOY cells, and interestingly their levels were significantly decreased in both hypoxic conditions, 1 and $0.1 \% \mathrm{O}_{2}$, coinciding with resistance to CPA and IFA. In the liver, CPA is 4-hydroxylated by CYP2B6 (44.8\%), CYP3A4 (24.7\%) and CYP3A5 ( 11.0\%), whereas IFA is also 4-hydroxylated by these isoforms although to a different extent: CYP3A4, 64.8\%; CYP3A5, 8.0\%; CYP2B6, $6.5 \%(14,32)$. In addition, hypoxia downregulates CYP1A1, CYP1A2, CYP2B6, CYP2C9 and CYP2C19, and decreases drug biotransformation (24). The reduction in CYP isoform expression would thus favor resistance to both CPA and IFA in DAOY cells.

Alterations in the expression of CYP enzymes in some neoplasias such as breast cancer, lymphomas and epithelial ovarian cancer, have been linked to resistance to ifosfamide, docetaxel, doxorubicin, etoposide and paclitaxel (43-46). Hypoxia and HIF-related pathways are linked to central cancer hallmarks by promoting metabolic reprogramming in tumor cells (47), that in turn alters the function of CYP enzymes by compromising their mono-oxygenase activity and redox reactions (48). However, through its binding to HRE, HIF-1 $\alpha$ has been shown to downregulate diverse genes, including the tissue factor pathway inhibitor (TFPI), peroxisome proliferator-activated receptors (PPAR $\alpha$ and PPAR $\gamma$ ), estrogen receptor $\alpha(E R-\alpha)$, peroxiredoxin 3 (Prx3), the vasodilator-stimulated phosphoprotein (VASP) and BID (49,50-52). In regard to CYP expression, in vivo and ex vivo models show that low oxygen levels also downregulate the expression of some CYP isoforms in different human or animal tissues, and cell lines $(21,22,53)$, therefore interfering with the action of a wide variety of anticancer drugs $(22,48,54)$. For example, moderate hypoxia was found to downregulate CYP3A4 expression in the HepG2 cell line, resulting in decreased metabolic activation of antineoplastic compounds $(21,22)$. Inhibition of CYP expression promoted by hypoxia may thus be considered as an adaptive response (48). Furthermore, overexpression in mice of an orthologous isoform of the human CYP46A1 appeared to be controlled by HIF-1 $\alpha$ via HRE (55), and hypoxia was found to downregulate CYP3A4 expression in the human hepatic progenitor HepaRG cell line, an effect attributed to the presence of an HRE sequence in the 5'-flanking region (-674/-661) of the CYP3A4 gene, although functional analyses failed to demonstrate the involvement of the HRE sequence (21).

We performed a preliminary in silico analysis on the sequences of the $57 \mathrm{CYP}$ human genes in the non-coding regions $(-3,500$ to $+1 \mathrm{pb})$ by alignment with CLUSTAL2W and JASPAR databases, and we identified HRE sequences (5'-RCGTG-3') with a high probability of functional activity (relative score $\geq 0.95$ ) in CYP2B6, CYP3A4 and CYP3A5. The location of the identified HRE sequences differed among these CYP isoforms, this location being closer to the region of transcription for CYP2B6 (-972 to $-965 \mathrm{pb})$ than for CYP3A4 (-3215 to -3208 and -3496 to $-3489 \mathrm{pb})$ or CYP3A5 (-3293 to $-3288 \mathrm{pb})$. This differential location may contribute to explain the pattern of regulation by HIF-1 $\alpha$ found in this study (CYP2B6 > CYP 3A4 = CYP3A5). However, functional assays are required to establish the biological activity of the putative HRE sequences.

Once metabolized into their active metabolites, CPA and IFA exert their cytotoxic effect on proliferating cells and it is thus noteworthy that hypoxia diminished the proliferation of DAOY cells by $\sim 30 \%$, in accord with the effect reported for prostate cancer PC-3 cells (56), colorectal cancer HT-29 and SW480 cells (57) and glioblastoma D566, U87 and U251 cells (58). This effect could be explained by the arrest in the G1 phase of the cell cycle (28-35\%) observed in this study, which could in turn be responsible, at least in part, for the diminished cytotoxic action of CPA and IFA, as reported for cervical cancer HeLa and breast cancer HTB-30 cells (28). Arrest in the G1 phase is controlled by several cyclins, including CDKN1B, and in DAOY cells both hypoxic conditions increased CDKN1B expression by 2.2 fold.

In order to corroborate whether the increased resistance to CPA and IFA promoted by hypoxia, alongside the inhibition of the expression of CYP2B6, CYP3A4 and CYP3A5, inhibition of cell proliferation and arrest of the cell cycle in G1 phase, were all effects dependent on the HIF-1 $\alpha$ pathway, the pharmacological inhibition by 2-ME of HIF-1 $\alpha$ activation was tested. 2-ME is a natural nonestrogenic metabolite derivative of $17 \beta$-estradiol with anti-angiogenic and pro-apoptotic activities, and has been tested in combination with canonical antineoplastic drugs in clinical phase II studies for the treatment of several types of cancer $(59,60)$. The mechanisms of action of 2-ME are complex and still unclear, but it has been proposed that the drug inhibits the polymerization of tubulin, thus disrupting the normal microtubule function necessary for HIF-1 $\alpha$ translocation to the nucleus (36).

Incubation with 2-ME produced additive or synergistic cytotoxic actions in combination with CPA or IFA, as reported also for paclitaxel in head and neck squamous cells, such as UM-SCC-1, -6, -11A, -11B and -46 cells (61), and sorafenib in hepatocellular carcinoma (HCC) cells (62). Our data support thus an important role for HIF-1 $\alpha$ in the drug resistance of medulloblastoma and confirm that its inhibition enhances treatment effectiveness.

HIF-1 $\alpha$ inhibition with 2-ME prevented the effect on CYP2B6 expression in the $1 \% \mathrm{O}_{2}$ condition but not in $0.1 \% \mathrm{O}_{2}$, as well as the effect of both hypoxic conditions on CYP3A4 expression, but failed to modify the downregulation of CYP3A5 expression. We do not have an explanation for the differential rescuing action of 2-ME on the expression of the three CYP isoforms studied. We propose that hypoxia induces HIF-1 $\alpha$-dependent transcriptional repression of CYP2B6, CYP3A4 and CYP3A5; however, our results do not discard additional HIF-1 $\alpha$-independent regulatory mechanisms, including the activation of transcriptional repressors such as the small heterodimer partner (SHP), which has been implicated in the inhibition of the CYP7A1 isoform under hypoxic conditions, and the downregulation of nuclear receptors implicated in the positive regulation of CYP2B6, CYP3A4 and CYP3A5, namely PPAR $\alpha$, PPAR $\gamma$ or ER- $\alpha$, as well as 
the constitutive androstane and pregnane $\mathrm{X}$ receptors, whose mRNA was found to be reduced by hypoxia $\left(1 \% \mathrm{O}_{2}, 24 \mathrm{~h}\right)$ in hepatic HepaRG stem cells $(21,51,52,63-65)$ In addition, post-transcriptional regulation of CYP expression implicates the action of diverse mRNA stabilizing molecules, microRNAs and long noncoding RNAs (66). Finally, 2-ME itself could act as a chemical modulator of CYP expression, because CYP substrates or their metabolites are capable of inducing CYP expression (19). Therefore, the role of hypoxia and HIF-1 $\alpha$ in CYP transcriptional regulation appears to be complex and probably does not only depend on HIF-1 $\alpha$ alone, with alternative mechanisms requiring further investigation.

Hypoxia $\left(0.1\right.$ and $\left.1 \% \mathrm{O}_{2}\right)$ increased CDKN1B expression in DAOY cells, and in human medulloblastoma tissues CDKN1B expression was detected in $57 \%$ of samples, with four positive out of five samples from desmoplastic tumors correlating with low apoptosis levels (67). Interestingly, 2-ME induces CDKN1B expression in leukemia and sarcoma cells; however, the mechanism underlying the effect of hypoxia is poorly understood $(68,69)$. In medulloblastoma cells, 2-ME treatment decreased CDKN1B expression in $1 \% \mathrm{O}_{2}$ but not in $0.1 \% \mathrm{O}_{2}$ and alternative regulatory mechanisms may therefore be involved in the lack of effect of 2-ME on the upregulation of CDKN1B expression in $0.1 \% \mathrm{O}_{2}$. For example, the p27 promoter contains binding sites for several transcription factors including Sp1, cAMP-response element (CRE), Myb, $\mathrm{NF}-\kappa \mathrm{B}$, and acute lymphocytic leukaemia-1 fused gene from chromosome $\mathrm{X}$ (70). Since $\mathrm{CRE}, \mathrm{NF}-\kappa \mathrm{B}$ and $\mathrm{Sp} 1$ are regulated by hypoxia, HIF-1 $\alpha$-indepent mechanisms, not prevented by $2-\mathrm{ME}$, could have contributed to the action of $0.1 \% \mathrm{O}_{2}$, explaining thus the lack of effect of 2-ME on the upregulation of CDKN1B.

In conclusion, in previous studies 2-ME has been proposed as a potent anticancer agent and as an alternative to the existing therapies for the treatment of diverse tumors, including medulloblastoma (71-73). This research and a few others provide experimental evidence that supports that 2-ME potentiates the chemotherapeutic effectiveness of certain antineoplastic agents, even under hypoxic conditions. Our results indicate that by stimulating HIF-1 $\alpha$ activity, hypoxia downregulates the expression of CYP2B6, CYP3A4 and CYP3A5, that in turn leads to decreased conversion of CPA and IFA into their active metabolites and thus to diminished cytotoxicity. Accordingly, the pharmacological inhibition of HIF-1 $\alpha$ enhanced CPA and IFA cytotoxic actions. These results support that the use of HIF- $1 \alpha$ inhibitors in combination with canonical antineoplastic agents provides a potential therapeutic alternative against medulloblastoma.

\section{Acknowledgements}

We thank Juan Escamilla-Sánchez and Raúl González-Pantoja for excellent technical assistance. Jesús Valencia-Cervantes holds a Conacyt graduate scholarship (21983).

\section{Funding}

The present study was partially funded by the Instituto Nacional de Pediatría, SSA (Programa E022 Recursos Federales Destinados a la Investigación, grant INP 39/2010), Conacyt (grants CB-2010/152919 to VMD-B and CB-2013/220448 to J-AA-M), and Cinvestav.

\section{Availability of data and materials}

Most data generated or analyzed during this study are included in this published article. Datasets that were not included (specified in the manuscript) are available from the corresponding authors on a reasonable request.

\section{Authors' contributions}

JVC, JAAM and VMDB conceived and designed the study; JVC, SHY and GAJ performed the experiments; JVC, SRE, DMF, JAAM and VMDB performed the analysis and interpretation of the data; JVC, SHY, GAJ, SRE, DMF, JAAM and VMDB were involved in drafting the manuscript and revising it critically. All authors revised and approved the manuscript and agree to be accountable for all aspects of the work in ensuring that questions related to the accuracy or integrity of any part of the work are appropriately investigated and resolved.

\section{Ethics approval and consent to participate}

Not applicable.

\section{Patient consent for publication}

Not applicable.

\section{Competing interests}

The authors declare that they have no competing interests.

\section{References}

1. Louis DN, Perry A, Reifenberger G, von Deimling A, Figarella-Branger D, Cavenee WK, Ohgaki H, Wiestler OD, Kleihues P and Ellison DW: The 2016 World Health Organization classification of tumors of the central nervous system: A summary. Acta Neuropathol 131: 803-820, 2016.

2. Massimino M, Biassoni V, Gandola L, Garrè ML, Gatta G, Giangaspero F, Poggi G and Rutkowski S: Childhood medulloblastoma. Crit Rev Oncol Hematol 105: 35-51, 2016.

3. Warnke PC, Kopitzki K, Timmer J and Ostertag CB: Capillary physiology of human medulloblastoma: Impact on chemotherapy. Cancer 107: 2223-2227, 2006.

4. Palmer SL: Neurodevelopmental impacts on children treatment for medulloblastoma: A review and proposed conceptual model. Dev Dis Res Rev 14: 203-210, 2008.

5. Huang GH, Xu QF, Cui YH, Li N, Bian XW and Lv SQ: Medulloblastoma stem cells: Promising targets in medulloblastoma therapy. Cancer Sci 107: 583-589, 2016.

6. Evans SM, Judy KD, Dunphy I, Jenkins WT, Hwang WT, Nelson PT, Lustig RA, Jenkins K, Magarelli DP, Hahn SM, et al: Hypoxia is important in the biology and aggression of human glial brain tumors. Clin Cancer Res 10: 8177-8184, 2004.

7. Michel G, Minet E, Ernest I, Roland I, Durant F, Remacle J and Michiels C: A model for the complex between the hypoxia-inducible factor-1 (HIF-1) and its consensus DNA sequence. J Biomol Struct Dyn 18: 169-179, 2000.

8. Hussein D, Estlin EJ, Dive C and Makin GW: Chronic hypoxia promotes hypoxia-inducible factor-1alpha-dependent resistance to etoposide and vincristine in neuroblastoma cells. Mol Cancer Ther 5: 2241-2250, 2006.

9. Liu L, Ning X, Sun L, Zhang H, Shi Y, Guo C, Han S, Liu J, Sun S, Han Z, et al: Hypoxia-inducible factor-1 alpha contributes to hypoxia-induced chemoresistance in gastric cancer. Cancer Sci 99: 121-128, 2008 
10. Rho JK, Choi YJ, Lee JK, Ryoo BY, Na II, Yang SH, Kim CH, Yoo YD and Lee JC: Gefitinib circumvents hypoxia-induced drug resistance by the modulation of HIF-1alpha. Oncol Rep 21: 801-807, 2009.

11. Doublier S, Belisario D, Polimeni M, Annaratone L, Riganti C, Allia E, Ghigo D, Bosia A and Sapino A: HIF-1 activation induces doxorubicin resistance in MCF7 3-D spheroids via P-glycoprotein expression: A potential model of the chemoresistance of invasive micropapillary carcinoma of the breast. BMC Cancer 12: 4, 2012.

12. Roncuzzi L, Pancotti F and Baldini N: Involvement of HIF-10 activation in the doxorubicin resistance of human osteosarcoma cells. Oncol Rep 32: 389-394, 2014.

13. Phillips RM: Targeting the hypoxic fraction of tumours using hypoxia-activated prodrugs. Cancer Chemo Pharmacol 77 441-457, 2016

14. Roy P, Yu L, Crespi C and Waxman D: Development of a substrate-activity based approach to identify the major human liver P-450 catalysts of cyclophosphamide and ifosfamide activation based on cDNA-expressed activities and liver microsomal P-450 profiles. Drug Metab Dispos 27: 655-666, 1999.

15. Dhaini HR, Thomas DG, Giordano TJ, Johnson TD, Biermann JS Leu K, Hollenberg PF and Baker LH: Cytochrome P450 CYP3A4/5 expression as a biomarker of outcome in osteosarcoma. J Clin Oncol 21: 2481-2485, 2003.

16. Murray GI, Patimalla S, Stewart KN, Miller ID and Heys SD Profiling the expression of cytochrome P450 in breast cancer. Histopathology 57: 202-211, 2010.

17. Chen TC, Sakaki T, Yamamoto K and Kittaka A: The roles of cytochrome P450 enzymes in prostate cancer development and treatment. Anticancer Res 32: 291-298, 2012.

18. Qixing M, Juqing X, Yajing W, Gaochao D, Wenjie X, Run S, Anpeng W, Lin X, Feng J and Jun W: The expression levels of CYP3A4 and CYP3A5 serve as potential prognostic biomarkers in lung adenocarcinoma. Tumour Biol 39: 1010428317698340 2017.

19. McFadyen MC, Melvin WT and Murray GI: Cytochrome P450 enzymes: Novel options for cancer therapeutics. Mol Cancer Ther 3: 363-371, 2004.

20. Rodriguez-Antona $C$ and Ingelman-Sundberg M: Cytochrome P450 pharmacogenetics and cancer. Oncogene 25: 1679-1691, 2006.

21. Legendre C, Hori T, Loyer P, Aninat C, Ishida S, Glaise D, Lucas-Clerc C, Boudjema K, Guguen-Guillouzo C, Corlu A and Morel F: Drug-metabolising enzymes are down-regulated by hypoxia in differentiated human hepatoma HepaRG cells: HIF-1alpha involvement in CYP3A4 repression. Eur J Cancer 45: 2882-2892, 2009.

22. Niemira M, Dastych J and Mazerska Z: Pregnane X receptor dependent up-regulation of CYP2C9 and CYP3A4 in tumor cells by antitumor acridine agents, C-1748 and C-1305, selectively diminished under hipoxia. Biochem Pharmacol 86: 231-241, 2013.

23. McErlane V, Yakkundi A, McCarthy HO, Hughes CM, Patterson LH, Hirst DG, Robson T and McKeown SR: A cytochrome P450 2B6 meditated gene therapy strategy to enhance the effects of radiation or cyclophosphamide when combined with the bioreductive drug AQ4N. J Gene Med 7: 851-859, 2005.

24. Fradette C and Souich P: Effect of hypoxia on cytochrome P450 activity and expression. Curr Drug Metab 5: 257-271, 2004.

25. Michaelis UR, Fisslthaler B, Barbosa-Sicard E, Falck JR, Fleming I and Busse R: Cytochrome P450 epoxygenases 2C8 and 2C9 are implicated in hypoxia-induced endothelial cell migration and angiogenesis. J Cell Sci 118: 5489-5498, 2005.

26. Fradette C, Batonga J, Teng S, Piquette-Miller M and du Souich P: Animal models of acute moderate hypoxia are associated with a down-regulation of CYP1A1, 1A2, 2B4, 2C5, and 2C16 and up-regulation of CYP3A6 and P-glycoprotein in liver. Drug Metab Dispos 35: 765-771, 2007.

27. Jewell UR, Kvietikova I, Scheid A, Bauer C, Wenger RH and Gassmann M: Induction of HIF-1alpha in response to hypoxia is instantaneous. FASEB J 15: 1312-1314, 2001.

28. Box AH and Demetrick DJ: Cell cycle kinase inhibitor expression and hypoxia-induced cell cycle arrest in human cancer cell lines. Carcinogenesis 25: 2325-2335, 2004.

29. Longley DB, Allen WL, McDermott U, Wilson TR, Latif T, Boyer J, Lynch M and Johnston PG: The roles of thymidylate synthase and p53 in regulating Fas-mediated apoptosis in response to antimetabolites. Clin Cancer Res 10: 3562-3571, 2004.
30. Chiche J, Brahimi-Horn MC and Pouysségur J: Tumour hypoxia induces a metabolic shift causing acidosis: A common feature in cancer. J Cell Mol Med 14: 771-794, 2010.

31. Swift LH and Golsteyn RM: Genotoxic anti-cancer agents and their relationship to DNA damage, mitosis, and checkpoint adaptation in proliferating cancer cells. Int J Mol Sci 15: 3403-3431, 2014.

32. Huang Z, Roy P and Waxman DJ: Role of human liver microsomal CYP3A4 and CYP2B6 in catalyzing $N$-dechloroethylation of cyclophosphamide and ifosfamide. Biochem Pharmacol 59: 961-972, 2000

33. O'Connor PM, Wassermann K, Sarang M, Magrath I, Bohr VA and Kohn KW: Relationship between DNA cross-links, cell cycle, and apoptosis in Burkitt's lymphoma cell lines differing in sensitivity to nitrogen mustard. Cancer Res 51: 6550-6557, 1991.

34. Shah MA and Schwartz GK: Cell cycle-mediated drug resistance: An emerging concept in cancer therapy. Clin Cancer Res 7: 2168-2181, 2001.

35. Sun C, Wang G, Wrighton KH, Lin H, Songyang Z,Feng XH and Lin X: Regulation of $\mathrm{p} 27^{\mathrm{kip} 1}$ phosphorylation and $\mathrm{G} 1$ cell cycle progression by protein phosphatase PPM1G. Am J Cancer Res 6 : 2207-2220, 2016.

36. Mabjeesh NJ, Escuin D, LaVallee TM, Pribluda VS, Swartz GM, Johnson MS, Willard MT, Zhong H, Simons JW and Giannakakou P: 2ME2 inhibits tumor growth and angiogenesis by disrupting microtubules and dysregulating HIF. Cancer Cell 3: 363-75, 2003.

37. Kaluz S, Kaluzová M, Liao SY, Lerman M and Stanbridge EJ: Transcriptional control of the tumor- and hypoxia-marker carbonic anhydrase 9: A one transcription factor (HIF-1) show? Biochim Biophys Acta 1795: 162-172, 2009.

38. Nordfors K, Haapasalo J, Korja M, Niemelä A, Laine J, Parkkila AK, Pastorekova S, Pastorek J, Waheed A, Sly WS, et al: The tumour-associated carbonic anhydrases CA II, CA IX and CA XII in a group of medulloblastomas and supratentorial primitive neuroectodermal tumours: An association of CA IX with poor prognosis. BMC Cancer 10: 148, 2010.

39. Svastová E, Zilka N, Zat'ovicová M, Gibadulinová A, Ciampor F, Pastorek J and Pastoreková S: Carbonic anhydrase IX reduces E-cadherin-mediated adhesion of MDCK cells via interaction with beta-catenin. Exp Cell Res 290: 332-345, 2003.

40. Wykoff CC, Beasley NJ, Watson PH, Turner KJ, Pastorek J, Sibtain A, Wilson GD, Turley H, Talks KL, Maxwell PH, et al: Hypoxia-inducible expression of tumor-associated carbonic anhydrases. Cancer Res 60: 7075-7083, 2000.

41. Sowa T, Menju T, Chen-Yoshikawa TF, Takahashi K, Nishikawa S, Nakanishi T, Shikuma K, Motoyama H, Hijiya K, Aoyama A, et al: Hypoxia-inducible factor 1 promotes chemoresistance of lung cancer by inducing carbonic anhydrase IX expression. Cancer Med 6: 288-297, 2017.

42. Liu J, Wang Q, Wu DC, Wang XW, Sun Y, Chen XY, Zhang KL and Li H: Differential regulation of CYP1A1 and CYP1B1 expression in resveratrol-treated human medulloblastoma cells. Neurosci Lett 363: 257-261, 2004.

43. Schmidt R, Baumann F, Knüpfer H, Brauckhoff M, Horn LC, Schönfelder M, Köhler U and Preiss R: CYP3A4, CYP2C9 and CYP2B6 expression and ifosfamide turnover in breast cancer tissue microsomes. Br J Cancer 90: 911-916, 2004.

44. Miyoshi Y, Taguchi T, Kim SJ, Tamaki Y and Noguchi S: Prediction of response to docetaxel by immunohistochemical analysis of CYP3A4 expression in human breast cancers. Breast Cancer 12: 11-15, 2005.

45. Rodríguez-Antona C, Leskelä S, Zajac M, Cuadros M, Alvés J, Moneo MV, Martín C, Cigudosa JC, Carnero A, Robledo M, et al: Expression of CYP3A4 as a predictor of response to chemotherapy in peripheral T-cell lymphomas. Blood 110: 3345-3351, 2007.

46. Zhu Z, Mu Y, Qi C, Wang J, Xi G, Guo J, Mi R and Zhao F: CYP1B1 enhances the resistance of epithelial ovarian cancer cells to paclitaxel in vivo and in vitro. Int J Mol Med 35: 340-348, 2015.

47. Yoshida GJ: Metabolic reprogramming: The emerging concept and associated therapeutic strategies. J Exp Clin Cancer Res 34: 111,2015

48. Donovan L, Welford SM, Haaga J, LaManna J and Strohl KP: Hypoxia-implications for pharmaceutical developments. Sleep Breath 14: 291-298, 2010. 
49. Erler JT, Cawthorne CJ, Williams KJ, Koritzinsky M, Wouters BG, Wilson C, Miller C, Demonacos C, Stratford IJ and Dive C: Hypoxia-mediated down-regulation of Bid and Bax in tumors occurs via hypoxia-inducible factor 1-dependent and -independent mechanisms and contributes to drug resistance. Mol Cell Biol 24: 2875-2889, 2004.

50. Cui XY, Skretting G, Tinholt M, Stavik B, Dahm AEA Sahlberg KK, Kanse S, Iversen N and Sandset PM: A novel hypoxia response element regulates oxygen-related repression of tissue factor pathway inhibitor in the breast cancer cell line MCF-7. Thromb Res 157: 111-116, 2017.

51. Li D, Du Y, Yuan X, Han X, Dong Z, Chen X, Wu H, Zhang J, $\mathrm{Xu} \mathrm{L}$, Han C, et al: Hepatic hypoxia-inducible factors inhibit PPAR $\alpha$ expression to exacerbate acetaminophen induced oxidative stress and hepatotoxicity. Free Radic Biol Med 110: 102-116, 2017.

52. Padró M, Louie RJ, Lananna BV, Krieg AJ, Timmerman LA and Chan DA: Genome-independent hypoxic repression of estrogen receptor alpha in breast cancer cells. BMC Cancer 17: 203, 2017

53. Fradette C, Bleau AM, Pichette V, Chauret N and Du Souich P: Hypoxia-induced down-regulation of CYP1A1/1A2 and up-regulation of CYP3A6 involves serum mediators. Br J Pharmacol 137: 881-891, 2002

54. Nishida CR, Lee M and de Montellano PR: Efficient hypoxic activation of the anticancer agent AQ4N by CYP2S1 and CYP2W1. Mol Pharmacol 78: 497-502, 2010.

55. Soncini M, Corna G, Moresco M, Coltella N, Restuccia U, Maggioni D, Raccosta L, Lin CY, Invernizzi F, Crocchiolo R, et al: 24-Hydroxycholesterol participates in pancreatic neuroendocrine tumor development. Proc Natl Acad Sci USA 113: E6219-E6227, 2016.

56. Anderson KM, Guinan $\mathrm{P}$ and Rubenstein $\mathrm{M}$ : The effect of normoxia and hypoxia on a prostate (PC-3) CD44/CD41 cell side fraction. Anticancer Res 31: 487-494, 2011.

57. Murono K, Tsuno NH, Kawai K, Sasaki K, Hongo K, Kaneko M, Hiyoshi M, Tada N, Nirei T, Sunami E, et al: SN-38 overcomes chemoresistance of colorectal cancer cells induced by hypoxia, through HIF1alpha. Anticancer Res 32: 865-872, 2012.

58. Richards R, Jenkinson MD, Haylock BJ and See V: Cell cycle progression in glioblastoma cells is unaffected by pathophysiological levels of hypoxia. Peer J 4: e1755, 2016.

59. Harrison MR, Hahn NM, Pili R, Oh WK, Hammers H, Sweeney C, Kim K, Perlman S, Arnott J, Sidor C, et al: A phase II study of 2-methoxyestradiol (2ME2) NanoCrystal ${ }^{\circledR}$ dispersion (NCD) in patients with taxane-refractory, metastatic castrate-resistant prostate cancer (CRPC). Invest New Drugs 29: 1465-1474, 2011.

60. Kulke MH, Chan JA, Meyerhardt JA, Zhu AX, Abrams TA, Blaszkowsky LS, Regan E, Sidor C and Fuchs CS: A prospective phase II study of 2-methoxyestradiol administered in combination with bevacizumab in patients with metastatic carcinoid tumors. Cancer Chemother Pharmacol 68: 293-300, 2011.

61. Ricker JL, Chen Z, Yang XP, Pribluda VS, Swartz GM and Van Waes C: 2-methoxyestradiol inhibits hypoxia-inducible factor 1alpha, tumor growth, and angiogenesis and augments paclitaxel efficacy in head and neck squamous cell carcinoma Clin Cancer Res 10: 8665-8673, 2004.
62. Ma L, Li G, Zhu H, Dong X, Zhao D, Jiang X, Li J, Qiao H, Ni S and Sun X: 2-methoxyestradiol synergizes with sorafenib to suppress hepatocellular carcinoma by simultaneously dysregulating hypoxia-inducible factor-1 and -2. Cancer Lett 355: 96-105, 2014.

63. Moon JY and Gwak HS: Role of the nuclear pregnane X receptor in drug metabolism and the clinical response. Receptors Clin Investig 2: e996, 2015.

64. Handschin C and Meyer UA: Induction of drug metabolism: The role of nuclear receptors. Pharmacol Rev 55: 649-673, 2003.

65. Plant N: The human cytochrome P450 sub-family: Transcriptional regulation, inter-individual variation and interaction networks. Biochim Biophys Acta 1770: 478-488, 2007.

66. Yu AM, Tian Y, Tu MJ, Ho PY and Jilek JL: MicroRNA pharmacoepigenetics: Posttranscriptional regulation mechanisms behind variable drug disposition and strategy to develop more effective therapy. Drug Metab Dispos 44: 308-319, 2016.

67. Adesina AM, Dunn ST, Moore WE and Nalbantoglu J: Expression of p27kip1 and p53 in medulloblastoma: Relationship with cell proliferation and survival. Pathol Res Pract 196: 243-250, 2000.

68. Batsi C, Markopoulou S, Kontargiris E, Charalambous C, Thomas C, Christoforidis S, Kanavaros P, Constantinou AI, Marcu KB and Kolettas E: Bcl-2 blocks 2-methoxyestradiol induced leukemia cell apoptosis by a p $27^{\mathrm{Kip1}}$-dependent G1/S cell cycle arrest in conjunction with NF- $\mathrm{BB}$ activation. Biochem Pharmacol 78: 33-44, 2009.

69. Maran A, Shogren KL, Benedikt M, Sarkar G, Turner RT and Yaszemski MJ: 2-methoxyestradiol-induced cell death in osteosarcoma cells is preceded by cell cycle arrest. J Cell Biochem 104: 1937-1945, 2008

70. Alkarain A and Slingerland J: Deregulation of p27 by oncogenic signaling and its prognostic significance in breast cancer. Breast Cancer Res 6: 13-21, 2004.

71. Kumar AP, Garcia GE, Orsborn J, Levin VA and Slaga TJ: 2-methoxyestradiol interferes with NF kappa B transcriptional activity in primitive neuroectodermal brain tumors: Implications for management. Carcinogenesis 24: 209-216, 2003.

72. Bruce JY, Eickhoff J, Pili R, Logan T, Carducci M, Arnott J, Treston A, Wilding G and Liu G: A phase II study of 2-methoxyestradiol nanocrystal colloidal dispersion alone and in combination with sunitinib malate in patients with metastatic renal cell carcinoma progressing on sunitinib malate. Invest New Drugs 30: 794-802, 2012.

73. Gorska M, Kuban-Jankowska A, Zmijewski MA, Gorzynik M, Szkatula M and Wozniak M: Neuronal nitric oxide synthase induction in the antitumorigenic and neurotoxic effects of 2-methoxyestradiol. Molecules 19: 13267-13281, 2014.

(i) $($ This work is licensed under a Creative Commons Attribution-NonCommercial-NoDerivatives 4.0 International (CC BY-NC-ND 4.0) License. 